\title{
SUBSURFACE STORAGE OF LIQUIDS IN THE FLORIDAN AQUIFER SYSTEM IN SOUTH FLORIDA
}

By Frederick W. Meyer

U.S. GEOLOGICAL SURVEY

Open-File Report 88-477

Prepared in cooperation with the

FLORIDA DEPARTMENT OF ENVIRONMENTAL REGULATION, FLORIDA GEOLOGICAL SURVEY, and the

SOUTH FLORIDA WATER MANAGEMENT DISTRICT

Tallahassee, Florida

1989 


\section{DEPARTMENT OF THE INTERIOR}

\section{MANUEL LUJAN, JR., Secretary}

\section{U.S. GEOLOGICAL SURVEY}

Dallas L. Peck, Director

For additional information write to:

District Chief

U.S. Geological Survey

Suite 3015

227 North Bronough Street

Tallahassee, Florida 32301
Copies of this report can be purchased from:

U.S. Geological Survey Books and Open-File Reports Section Federal Center, Building 810

Box 25425

Denver, Colorado 80225 


\section{CONTENTS}

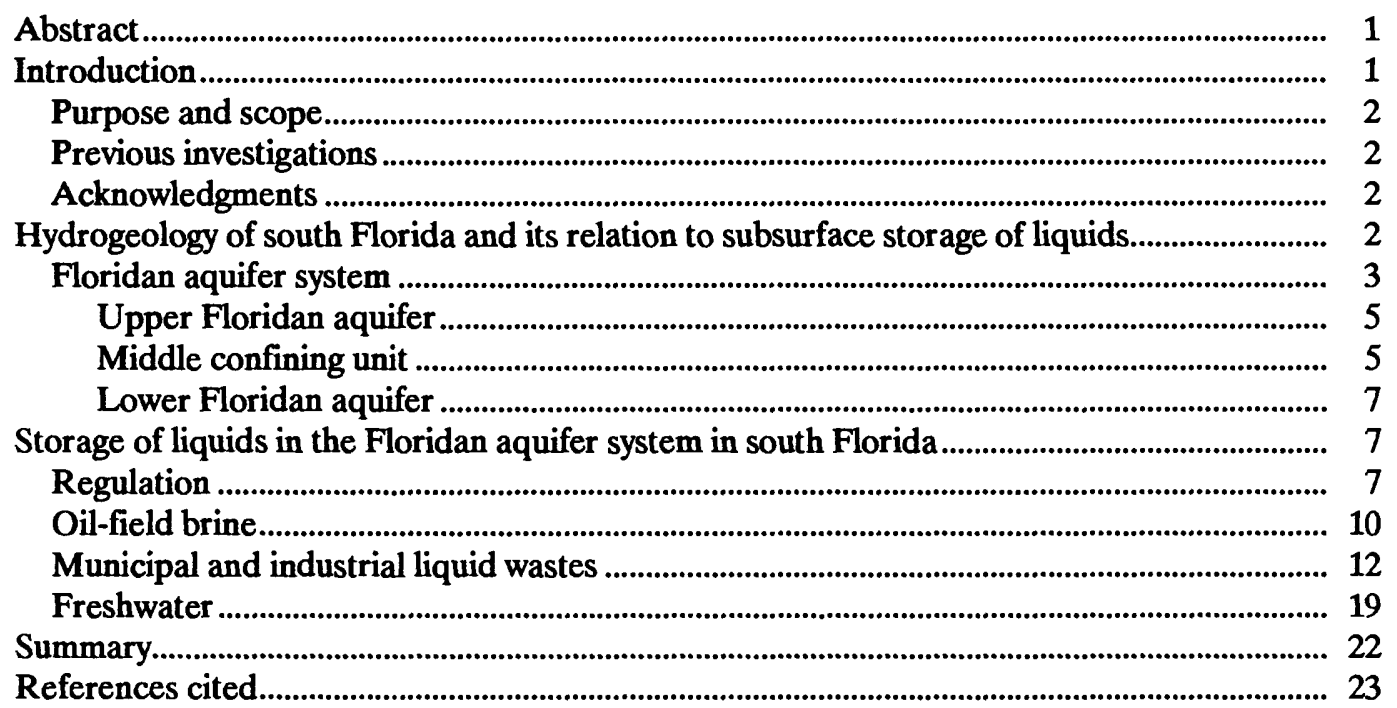

\section{ILLUSTRATIONS}

Figure 1. Idealized hydrogeologic cross section through peninsular Florida showing concept of cyclic flow of seawater induced by geothermal heating

2. Map of peninsular Florida, showing the potentiometric surface in May 1980, Upper Floridan aquifer.

3. Diagram showing fluid temperature and hydrogeologic units in well G-2334 at site 9, Fort Lauderdale

4. Map of south Floridan Plateau, showing temperature of saltwater in the Boulder Zone of the Lower Floridan aquifer

5. Map of south Florida, showing location of oil fields, municipal and industrial deep-well injection systems, and freshwater injection pilot projects, 1983

6. Graph showing annual brine and oil production for south Florida oil fields, 1943-83. 


\section{ILLUSTRATIONS--Continued}

Figure 7. Diagram showing hydrogeology and typical construction of oil-field brine disposal wells

8. Graph showing annual and cumulative volumes of municipal and industrial liquid-waste injection, 1959-83

9. Diagram showing hydrogeology and typical construction characteristics of a municipal wastewater-disposal well

10. Diagram showing hydrogeology and typical construction characteristics of an industrial liquid-waste disposal well 18

\section{TABLES}

Table 1. Analyses of selected oil-field brine, south Florida

2. Summary of brine production and disposal for oil fields in south Florida, 1943-83

3. Summary of municipal and industrial injection of liquid wastes in south Florida, 1959-83

4. Selected water-quality characteristics of injectant, local water supply, and native ground water in the Boulder Zone at sites 15 and 19 in Palm Beach County and at site 22 in Dade County

5. Average rate of municipal and industrial imjection, 1959-84

6. Results of mjection, storage, and recovery tests at sites 24 (Palm Beach County, 1975-76), 25 (Dade County, 1975-80), 26 (Lee County, 1980-82), and 27 (St. Lucie County, 1982-83)

7. Results of wastewater recovery tests at site $\mathbf{1 4}$ in Broward County, 1975-77 


\title{
SUBSURFACE STORAGE OF LIQUIDS IN THE FLORIDAN AQUIFER SYSTEM IN SOUTH FLORDA
}

\author{
By Frederick W. Meyer
}

\begin{abstract}
The Floridan aquifer system in south Florida is composed chiefly of carbonate rocks that range in age from early Miocene to Paleocene. The top of the Floridan aquifer system generally occurs at depths ranging from 500 to 1,000 feet, and the average thickness is about 3,000 feet. In south Florida, the Floridan aquifer system is divided into three general hydrogeologic units that include: (l) the Upper Floridan aquifer, (2) the middle confining unit, and (3) the Lower Floridan aquifer. The Upper Floridan aquifer contains brackish ground water, the middle confining unit contains salty ground water, and the Lower Floridan aquifer contains salty ground water that compares chemically to modern seawater. A thick, cavernous dolostone in the Lower Floridan aquifer, called the Boulder Zone, is one of the most permeable carbonate units in the world (transmissivity of about $2.5 \times 10^{7} \mathrm{feet}$ squared per day). Ground-water movement in the Upper Floridan aquifer is generally from the area of highest head in central Florida, eastward to the Straits of Florida, westward to the Gulf of Mexico, and, to a lesser extent, southward.

The principal use of the Floridan aquifer system in south Florida is for subsurface storage of liquid waste. The Boulder Zone of the Lower Floridan aquifer is extensively used as a receptacle for injected treated municipal wastewater, oil-field brine and, to a lesser extent, industrial wastewater. Pilot studies indicate a potential for cyclic storage of freshwater in the Upper Floridan aquifer in south Florida.

Injection of nontoxic liquid wastes into deep, saline parts of the Floridan aquifer system as a pollution-control measure began in 1943 with injection of oil-field brine in southwest Florida. Since then, the practice has quickly expanded, and many high-capacity municipal and industrial injection wells are now in operation in southeast Florida.

Injection wells that are associated with production of oil and gas are administered by the Florida Geological Survey, Department of Natural Resources, whereas all other injection wells are administered by the Florida Department of Environmental Regulation. Since 1943, the Floridan aquifer system has been used as a receptacle for oil-field brine. During 1943-83, about 8.1 billion gallons of brine were produced with about 3.2 billion gallons of oil. Of the 8.1 billion gallons of brine, about 7.1 billion gallons were injected into the Floridan aquifer system. During 1959-83, about 112.1 billion gallons of nontoxic liquid wastes were injected into the Floridan aquifer system by municipal wastewater-treatment systems and industry. The average rate of injection increased from about 0.3 million gallons per day in 1959 to 73.5 million gallons per day in 1983. In 1984, the estimated rate of injection was 112 million gallons per day.

\section{INTRODUCTION}

Subsurface storage is the practice of emplacing fluids in permeable underground rocks (aquifers) by gravity flow or pressure-induced injection through wells. The receiving rocks must have sufficient confinement, porosity, and permeability to accept the fluids without endangering underground sources of drinking water. In most cases, the fluids are nontoxic liquid wastes that cannot easily be disposed of at the surface. In some cases, however, the fluids are valuable and are temporarily emplaced underground for later recovery. The subsurface storage practice is commonly referred to as "underground injection," "deep disposal," and "deep-well injection." Regulation of the practice is the responsibility of the U.S. Environmental Protection Agency, the Florida Department of Environmental Regulation, and the Florida Department of Natural Resources.
\end{abstract}


Injection of nontoxic liquid wastes into the saline water of the Boulder Zone as a pollutioncontrol measure began in 1943 with the injection of brine at an oil field a few miles east of Naples. Subsequently, the practice has expanded rapidly, and many high-capacity, municipally operated, wastewater-injection wells are now in use along the southeast coast of Florida (Vernon, 1970; Vecchioli and others, 1979; and Meyer, 1984). Determination of the amount and extent of injection was necessary in order to assess its impact on water supply.

\section{Purpose and Scope}

The purposes of this report are to: (1) describe the hydrogeology of the Floridan aquifer system in south Florida and its relation to the practice of subsurface storage, (2) discuss the rules and regulations concerned with the control of underground (subsurface) injection, (3) identify and quantify the types of liquid wastes which have been injected into the Floridan aquifer system, and (4) identify and summarize the results of pilot studies concerned with the storage of freshwater in the Floridan aquifer system.

Water-bearing zones in the Floridan aquifer system that were receiving liquid wastes as of 1984 are identified and described. Legislation by Federal and State Governments that regulate underground injection is discussed. Data are presented on the injected amounts of brine from oil fields, treated wastewater from municipalities, liquid wastes from industries, and amounts of freshwater stored and recovered by pilot studies designed to explore use of freshwater injection, storage, and recovery as a water-supply alternative.

\section{Previous Investigations}

Various aspects of subsurface storage of liquid wastes into the Floridan aquifer system in south Florida were reported by Garcia-Bengochea and Vernon (1969), Vernon (1970), Vecchioli and others (1979), Meyer (1971; 1974; 1984), Miller (1979), Merritt and others (1983), and Wedderburn and Knapp (1983). Regional aspects of the hydrogeology of the Floridan aquifer system in south Florida were reported by Stringfield (1936; 1953; 1966), Parker and others (1955), Kohout (1965; 1967), Vernon (1970), and Miller (1986).

\section{Acknowledgments}

The author thanks the following people who provided data and technical assistance for the study: S.R. Windham, C.H. Tootle, and B.E. Lane, Florida Geological Survey, Department of Natural Resources, Tallahassee, Fla.; R.S.DeHan and R.J. Duerling, Florida Department of Environmental Regulation (FDER), Tallahassee, Fla.; R.M. Duke, FDER, West Palm Beach, Fla.; Negandra Khanal and L.A. Wedderburn, South Florida Water Management District, West Palm Beach, Fla.; members of the FDER South Florida Technical Advisory Committee; A.E. Coker, U.S. Environmental Protection Agency, Region IV, Atlanta, Ga.; V.P. Amy and Abe Kreitman, Geraghty and Miller, Inc., West Palm Beach, Fla.; J.I. Garcia-Bengochea and L.A. Bell, $\mathrm{CH}_{2} \mathrm{M}$ Hill, Inc., Gainesville, Fla.; R.F. La Rovere, Quaker Oats Chemical, Inc., Belle Glade, Fla.; R.J. Kerrn, Alsay-Pippin Corporation, Lake Worth, Fla.; P.E. Robinson, Hazen and Sawyer, Inc., Hollywood, Fla.; J.R. Peralta, General Development Utilities, Inc., Miami, Fla.; W.R. Mehner, City of Fort Lauderdale, Fla.; Garrett Sloan, Miami-Dade Water and Sewer Authority, Miami, Fla.; E.E. Mitchell, City of Stuart, Fla.; Charlie O'Connor, City of West Palm Beach, Fla.; Jerry David, City of Margate, Fla.; Joe Stidham, Hercules, Inc., Vero Beach, Fla.; M.S. Mathews, Exxon, U.S.A., New Orleans, La., and John Ford, Sun Company, Longview, Tex.

\section{HYDROGEOLOGY OF SOUTH FLORIDA AND ITS RELATION TO SUBSURFACE STORAGE OF LIQUIDS}

South Florida is underlain by rocks of Cenozoic age to a depth of about 5,000 feet. These rocks are principally carbonates (limestone and dolostone) with minor amounts of evaporites (gypsum and anhydrite) in the lower part and clastics (sand and clay) in the upper part. The movement of ground water from inland areas to the ocean or vice versa occurs principally through the carbonate rocks.

Evaporites in the Cedar Keys Formation of Paleocene age probably comprise the lower confining unit or base of the active flow system (fig. 1). Overlying the evaporites are limestones and dolostones ranging in age from Paleocene to early 
Miocene that comprise the Floridan aquifer system. Ground water in the Floridan aquifer system in south Florida contains ground water that is generally too saline for most water supplies. The Lower Floridan aquifer contains ground water that is similar in chemical composition to seawater and is chiefly used as a receptacle for injected liquid wastes; the Upper Floridan aquifer contains brackish water and is chiefly used as a source for limited industrial or agricultural supply and for feedwater to desalting plants. Pilot studies indicate that the upper part of the Floridan aquifer system in south Florida has the potential for cyclic storage of freshwater (Merritt and others, 1983).

Overlying the Floridan aquifer system are alternating beds of sand, clay, marl, and limestone in the Tampa Limestone and Hawthorn Formation (both of Miocene age) that contain intermediate artesian aquifers and comprise the upper confining unit for the Floridan aquifer system. In southeast Florida, clay in the Tamiami Formation of Pliocene age is included in the upper confining unit. Limestone aquifers in Miocene deposits are important local sources of water for supply in southwest Florida.

Overlying the upper confining unit are limestones and sands of the Tamiami Formation and undifferentiated Pleistocene deposits of limestone and sand that comprise the surficial aquifer system and contain unconfined ground water. The surficial aquifer system is the major source of potable water in south Florida.

\section{Floridan Aquifer System}

The Floridan aquifer system is defined (Miller, 1986) as a vertically continuous sequence of permeable carbonate rocks of Tertiary age that are hydraulically connected in varying degrees, and whose permeability is generally several orders of magnitude greater than that of those rocks that bound the system above and below. In Florida, it includes rocks ranging in age from early Miocene to Paleocene.

In southeast Florida, the Floridan aquifer system includes (from shallowest to deepest) all or part of the Suwannee Limestone of Oligocene age, the Ocala Limestone of late Eocene age, the Avon Park Formation of middle Eocene age, the Oldsmar Formation of early Eocene age, and the upper part of the Cedar Keys Formation of Paleocene age (fig. 1). In southwest Florida, it locally includes the lower part of the Tampa Limestone of early Miocene age.

Some investigators place the top of the Floridan aquifer system in the lower part of the Hawthorn Formation of middle Miocene age wherever it contains permeable limestone hydraulically connected to deeper layers (Parker and others, 1955; Stringfield, 1966). Using regional criteria based largely on lithologic changes in the rocks, Miller (1986) placed the top of the Floridan aquifer system at or near the top of the Suwannee Limestone in southwest Florida and at or near the base of the Suwannee Limestone in southeast Florida. The top of the Floridan aquifer system, as used in this report, ranges from about 500 to 1,000 feet in depth. The base of the Floridan aquifer system (the lowest confining unit) generally coincides with the top of evaporite beds in the Cedar Keys Formation (Miller, 1986), and it ranges from 3,500 to 4,100 feet in depth.

The rocks that comprise the Floridan aquifer system vary greatly in permeability so that it resembles a "layer cake" composed of many alternating zones of low and high permeability. Crossflow (vertical flow) between permeable zones probably occurs through sinkholes and fractures. However, the amount of crossflow probably is small compared to the amount of horizontal flow. The zones of highest permeability generally occur at or near unconformities and generally are parallel to bedding planes.

The temperature of ground water in the Floridan aquifer system in areas along the Atlantic coast generally decreases with increasing depth. Ground-water temperatures generally are coolest along the southeast coast where the temperature of seawater in the adjacent Straits of Florida is the lowest. Ground-water salinity is generally highest in coastal parts of south Florida and in the lower part of the Floridan aquifer system because of inland circulation of seawater (Kohout, 1965). Anomalies frequently occur inland which probably is because of local upwelling of warm saltwater through fractures and sinkholes. 


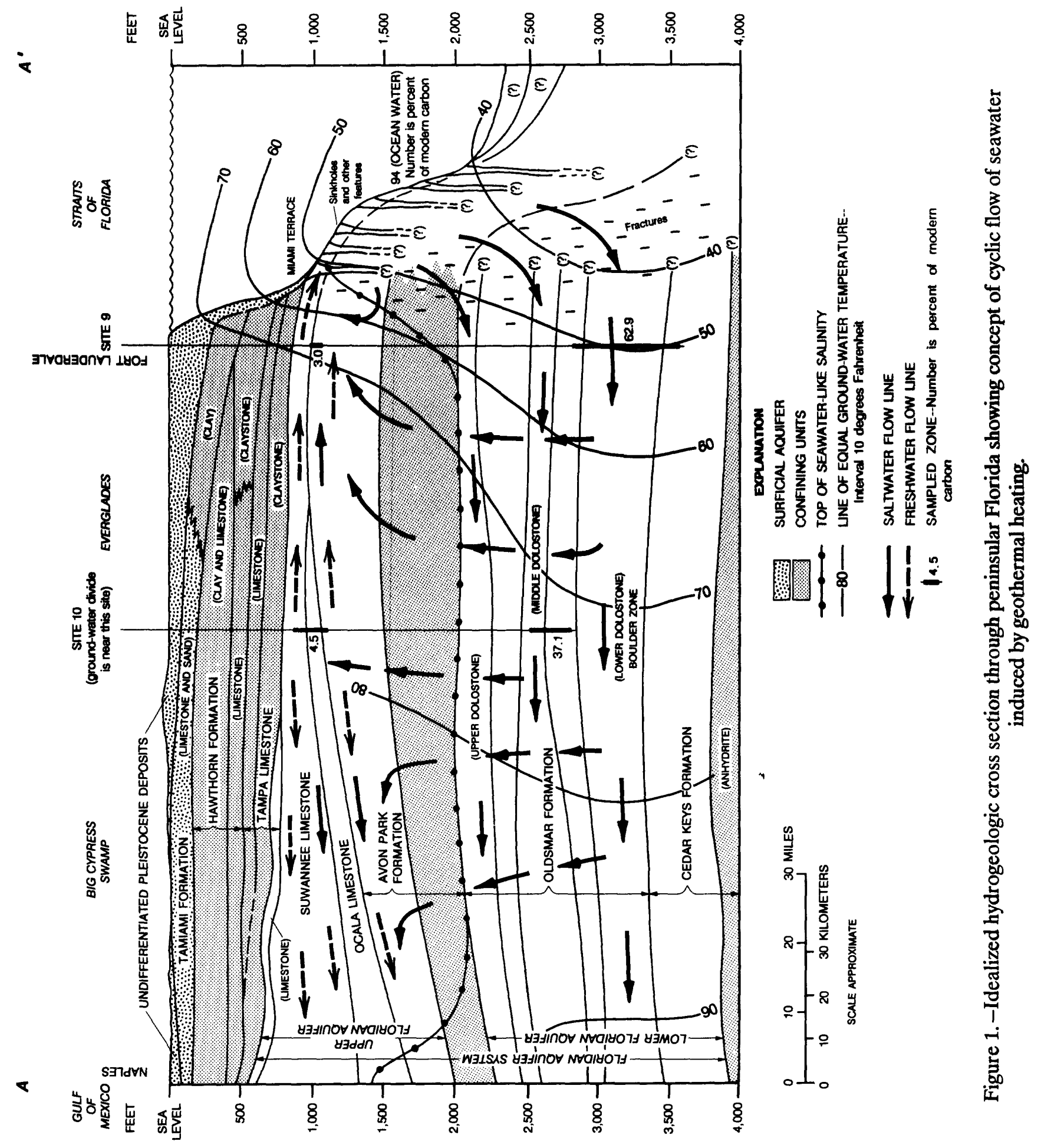


In southern Florida, the Floridan aquifer system can generally be divided largely on the basis of the geology, hydrochemistry, and hydraulics interpreted from data obtained by the authors (Meyer, 1987) at the Alligator Alley test well (fig. 4 , site 10) into three hydrogeologic units as follows:

1. The Upper Floridan aquifer, which contains brackish ground water. The specific conductance of the water ranges from about 1,000 to $25,000 \mu \mathrm{S} / \mathrm{cm}$ ((microsiemens per centimeter at $77^{\circ} \mathrm{F}$ $\left.\left(25^{\circ} \mathrm{C}\right)\right)$ and averages about $5,000 \mu \mathrm{S} / \mathrm{cm}$.

2. The middle confining unit, which contains salty ground water. The specific conductance of the water ranges from about 35,000 to $37,000 \mu \mathrm{S} / \mathrm{cm}$ and averages about $36,000 \mu \mathrm{S} / \mathrm{cm}$.

3. The Lower Floridan aquifer contains salty ground water that is similar in composition to modern seawater. The specific conductance of the water ranges from about 43,000 to $50,000 \mu \mathrm{S} / \mathrm{cm}$ and averages about $49,000 \mu \mathrm{S} / \mathrm{cm}$.

Upper Floridan Aquifer

The Upper Floridan aquifer in south Florida consists chiefly of permeable zones in the Tampa Limestone, Suwannee Limestone, and Ocala Limestone and in the upper part of the Avon Park Formation. On the basis of aquifer tests and a regional flow model, the transmissivity is estimated to range from 10,000 to $250,000 \mathrm{ft}^{2} / \mathrm{d}$ (Bush, 1982). Ground water in the aquifer is virtually brackish. The salinity of the ground water generally increases with increasing depth and with distance downgradient and southward from central Florida. Ground-water temperatures also generally increase downgradient and southward from the recharge area in central Florida. However, temperatures along the southeast coast are lowest (about $70.0^{\circ} \mathrm{F}$ ) because of heat transfer to the Atlantic Ocean (Straits of Florida) (Sproul, 1977, p. 75 ) and/or to heat transfer to cooler saltwater in the Lower Floridan aquifer (Kohout, 1965). Temperature and salinity anomalies in inland areas are related to upwelling ground water from the Lower Floridan aquifer.
Water movement chiefly is through highly permeable zones of dissolution at or near the top of each formation. Ground-water movement in May 1980 was generally from the area of highest head near Polk City in central Florida to the Gulf of Mexico and to the Atlantic Ocean (fig. 2). The area of highest freshwater head is herein referred to as the "Polk City high." Before development (late 1800 's or early 1900 's), the head in south Florida probably was 5 to 10 feet higher than present. As a result of water use and sea-level rise, hydraulic gradients in south Florida have been reduced, thereby causing a decrease of natural discharge by submarine springs along the southeast coast and movement of seawater inland to a new position of equilibrium. The concave shape of the contours on the 1980 potentiometric surface map along the southeast coast indicates discharge by submarine springs in the submerged karst on the Miami Terrace between Fort Lauderdale and Miami.

\section{Middle Confining Unit}

The middle confining unit of the Floridan aquifer system chiefly consists of the lower part of the Avon Park Formation but locally includes the upper part of the Oldsmar Formation (formerly the Lake City Limestone). The permeability of the unit is relatively low, and it generally separates the Upper Floridan aquifer, containing brackish ground water, from the Lower Floridan aquifer, containing ground water that compares closely to seawater. Hydraulic connection between the upper and lower aquifers by sinkholes and fractures that transect the middle confining unit is inferred. Ground-water movement in south Florida is estimated to be chiefly upward from the Lower Floridan aquifer through the middle confining unit, then laterally toward the ocean through the Upper Floridan aquifer. Salinity varies greatly at the top of the middle confining unit as the upward moving saltwater is blended with the seaward-flowing freshwater in the Upper Floridan aquifer. As previously stated, temperature and salinity anomalies in the Upper Floridan aquifer are evidence of upwelling saltwater from the lower part of the Floridan aquifer system. 


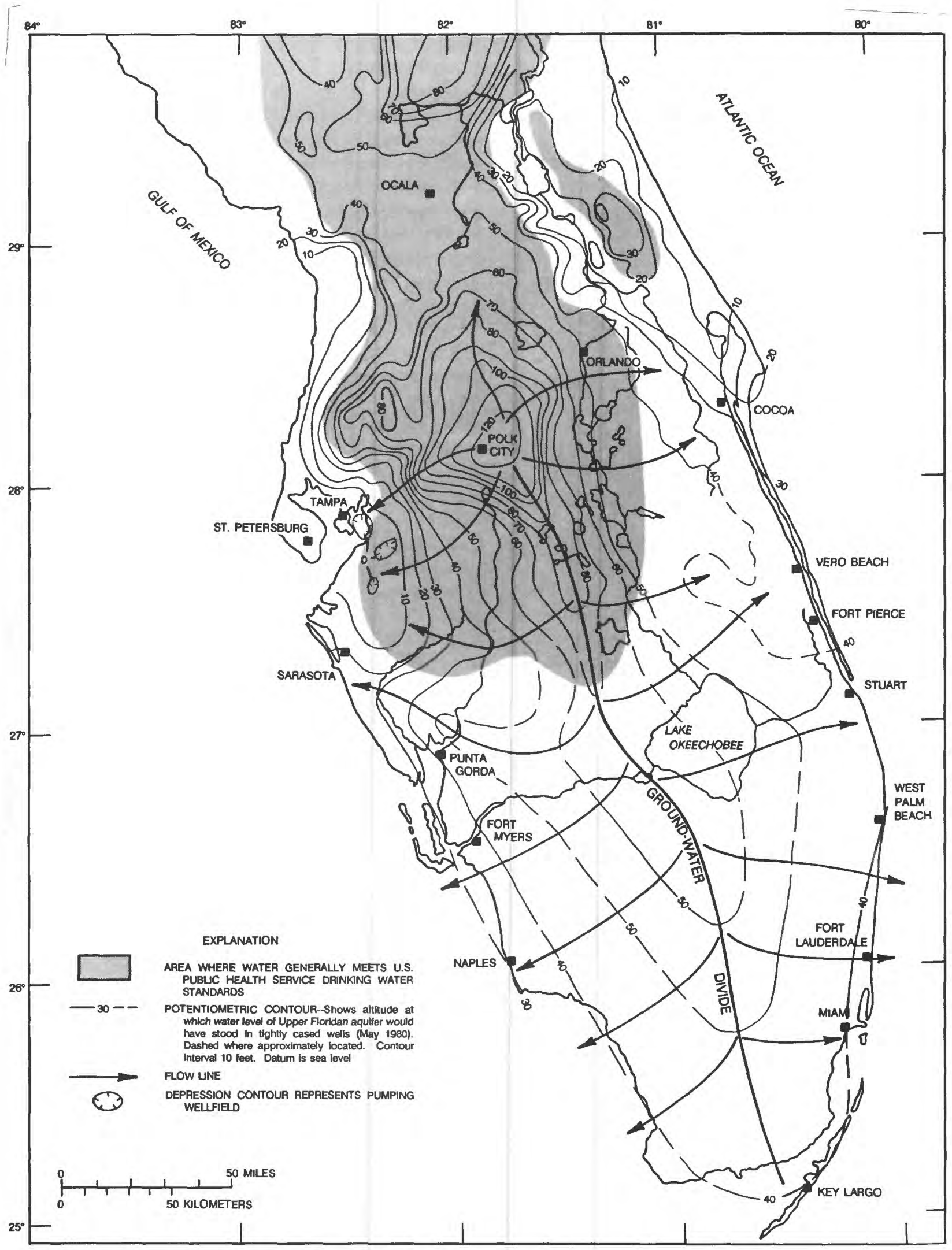

Figure 2.-Peninsular Florida, showing the potentiometric surface in May 1980, Upper Floridan aquifer. (Modified from Johnston and others, 1981.) 


\section{Lower Floridan Aquifer}

The Lower Floridan aquifer consists chiefly of the Oldsmar Formation and, to a lesser degree, the upper part of the Cedar Keys Formation. Ground water in the Lower Floridan aquifer compares chemically to that of modern seawater. Three permeable dolostones within the Oldsmar Formation are separated by less-permeable limestones. The transmissivity of the lower dolostone (locally called the Boulder Zone) (Miller, 1986, p. B65-B66) ranges from about $3.2 \times 10^{6} \mathrm{ft}^{2} / \mathrm{d}$ (Meyer, 1974) to $2.5 \times 10^{7} \mathrm{ft}^{2} / \mathrm{d}$ (Singh and others, 1983), whereas that for the overlying dolostones probably is an order of magnitude less. In southeast Florida, hydraulic connection between the lower and intermediate dolostones is inferred from pumping tests and from the presence of sinkholes and fractures; however, hydraulic connection between the intermediate and upper dolostones probably is poor, and locally the upper dolostone may be more closely related to the middle confining unit than to the Lower Floridan aquifer. In southwest Florida, drilling data suggest that dolostones are hydraulically connected although head data and aquifer tests are lacking to confirm this interpretation.

A pronounced temperature anomaly occurs in the Lower Floridan aquifer with the lowest measured temperature $\left(50.5^{\circ} \mathrm{F}\right.$ or $\left.10.3^{\circ} \mathrm{C}\right)$ in a deep disposal well (G - 2334) at Fort Lauderdale (fig. 3). Temperatures generally increase from the Straits of Florida inland toward the center of the Floridan Plateau (figs. 1 and 4). Kohout (1965) hypothesized circulation of cold seawater inland from the Straits of Florida through the lower part of the Floridan aquifer system by geothermal heat flow. Attempts to calculate hydraulic gradients in the Lower Floridan aquifer to verify ground-water movement have, thus far, been unsuccessful because of the lack of reliable head data and to transitory effects of tides (ocean, Earth, and atmospheric). However, recent measurements of head in the waters of the Boulder Zone at site 9 (fig. 4) in well G-2334 and site 10 (fig. 4) in well G-2296 substantiate the Kohout hypothesis.

\section{STORAGE OF LIQUIDS IN THE FLORIDAN AQUIFER SYSTEM IN SOUTH FLORIDA}

\section{Regulation}

The practice of injecting nontoxic liquid wastes into saline parts of the Floridan aquifer system began in 1943 at an oil field in Collier County (fig. 5 , site 1) where oil-field brine was injected into the cavernous, saltwater-filled Boulder Zone of the Lower Floridan aquifer (Vernon, 1970). The injection of treated municipal wastewater into

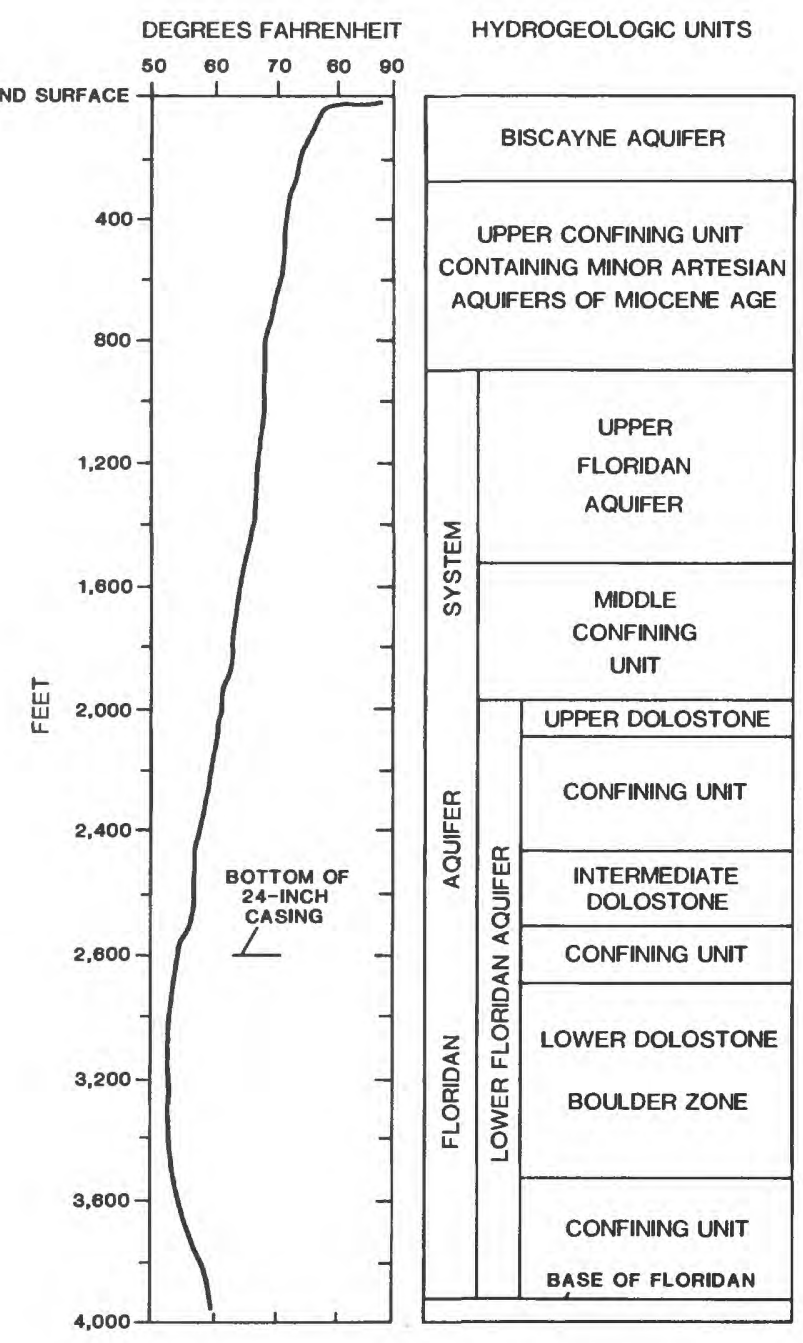

Figure 3.-Fluid temperature and hydrogeologic units in well G-2334 at site 9, Fort Lauderdale. 


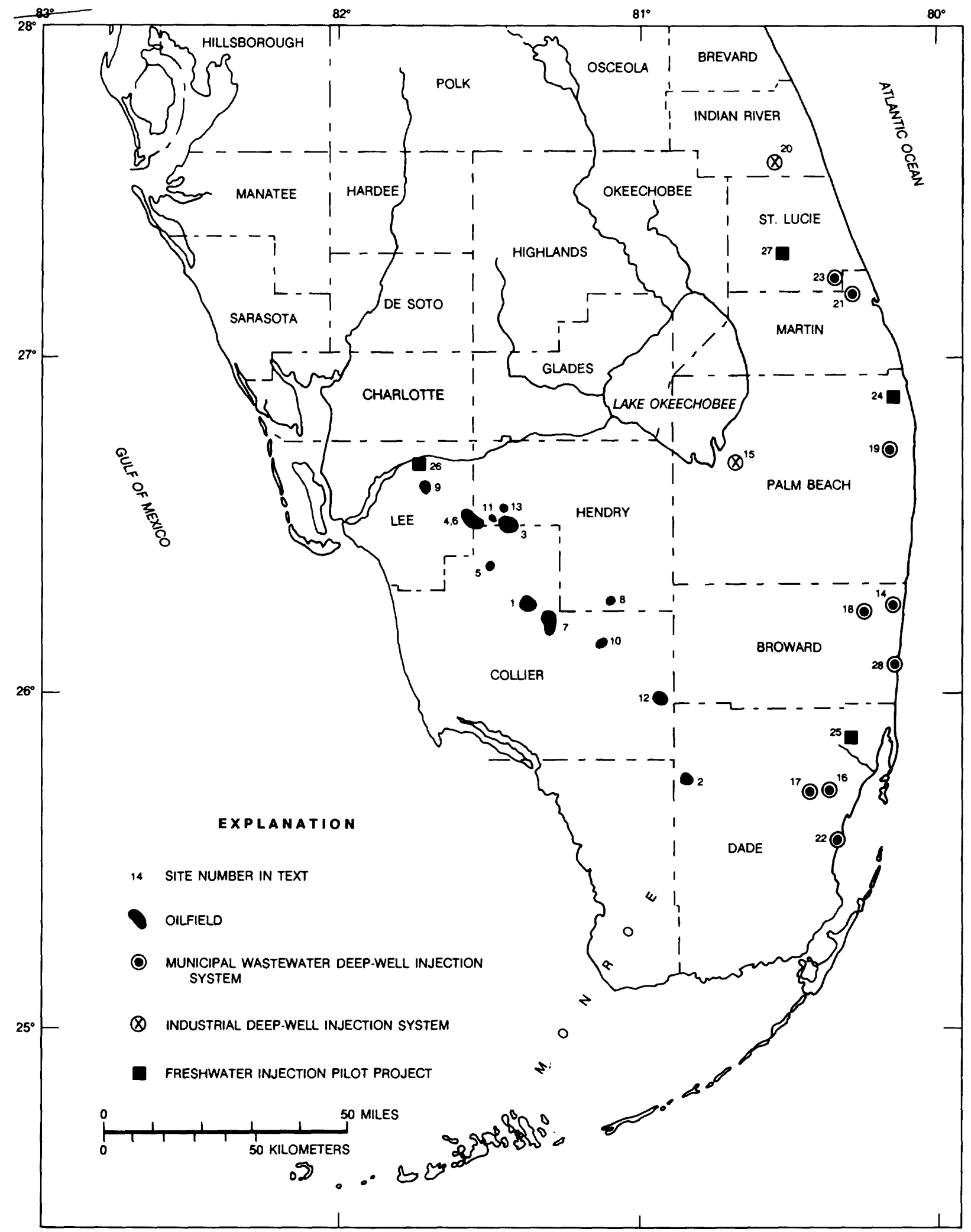

Figure 5.-South Florida, showing location of oil fields, municipal and industrial deep-well injection systems, and freshwater injection pilot projects, 1983. 
Before 1970, the regulation of injection wells was a principal function of the Florida State Board of Health (Chapter 17C-3, Florida Administrative Code), and permits were issued as though the injection well was a drainage well. The criterion for issuing the permit was that the receiving rocks contain water which was nonpotable and salty; that is, water with a chloride concentration equal to or greater than $1,500 \mathrm{mg} / \mathrm{L}$. Subsequent assignment of the permitting function to the Florida Department of Pollution Control in 1970 led to more stringent regulation, and permits were issued only after thorough review by the Florida Department of Natural Resources, the State Board of Health, and the local Water Management District in consultation with the U.S. Geological Survey.

As injection wells expanded rapidly in the early 1970's, the Federal Government became increasingly concerned about the impact of deep-well disposal practices on drinking water supplies. In 1974, Congress passed the Safe Drinking Water Act (Public Law 93-523, as amended by Public Law 95-190), which required the U.S. Environmental Protection Agency (EPA) to develop and publish regulatory and minimum requirements to control underground injection. The regulations, called underground injection control (UIC) rules, were published in the Congressional Federal Register on June 24, 1980 (chapter 40, parts 122 and 146). Responsibility for development and enforcement of UIC rules, along the lines established by EPA, was delegated to the Florida Department of Environmental Regulation in 1983 for all but class II injection wells. The regulation of injection wells associated with oil and gas production (class II injection wells) is administered by the Florida Geological Survey, Florida Department of Natural Resources (Chapter 377, Florida Statutes and Rules 16C-25 through 16C-30, Florida Administrative Code), and by the EPA.

All injection wells other than those associated with oil and gas production are regulated by the Florida Department of Environmental Regulation (1982) (Chapter 17-28, Florida Administrative Code). The purpose of the UIC rules is to protect the quality of the State's underground sources of drinking water and to prevent degrada- tion of the quality of other aquifers adjacent to the injection zone. The rules regulate the location, construction, operation, and monitoring of injection wells so that the injection does not interfere with any designated use of ground water or cause violations of water-quality standards for underground sources of drinking water. Underground sources of drinking water are defined by the State as an aquifer or its portion that supplies drinking water for human consumption, or is classified by rule 17-3.403 (Florida Administrative Code) as class $\mathbf{G}-\mathrm{I}$ or $\mathrm{G}-\mathrm{II}$ water and is not an exempted aquifer. In general, ground water with a total dissolved solids concentration of $10,000 \mathrm{mg} / \mathrm{L}$ or less is protected by the UIC rules. For detailed information on the standards and permitting procedures for injection wells, the reader should contact the appropriate State agency.

This report is concerned with class I injection wells, those which are used to inject municipal and industrial wastewater; class II injection wells, those which are used to inject oil-field brine; and class V, group 2, injection wells, those which are used to inject freshwater for storage.

\section{Oil-Field Brine}

Since the discovery of oil in south Florida in 1943 at a field in Collier County, 12 other oil fields have been discovered that have produced commercial amounts of crude oil (fig. 5). Oil is produced chiefly from Lower Cretaceous limestone, called the Sunniland Zone by drillers, which underlies the region at depths ranging from 11,000 to 12,000 feet. Along with the crude oil produced are large quantities of saltwater called "brine." The brine is several times saltier than seawater, and small amounts spilled on the surface can render a potable water supply useless for many years. Analyses of selected oil-field brine are shown in table 1. Chloride concentrations for the brine ranged from 108,000 to $164,570 \mathrm{mg} / \mathrm{L}$, compared to about $19,200 \mathrm{mg} / \mathrm{L}$ for seawater.

Total oil production for the 13 fields during 1943-83 was about 77.3 million bbl (barrels) (about 3.2 billion gallons), and brine production was about 193.2 million bbl (about 8.1 billion gallons). The largest producer of oil and brine (fig. 5 , site 4) yielded about 35.1 million bbl of oil and about 72.7 million bbl of brine during 1966-83. 
Table 1.--Analyses of selocted oil-field brine, south Florida

\begin{abstract}
[Concentrations shown in milligrams per 1iter; density show in grams per cubic centimeter $\left(8 / \mathrm{cm}^{3}\right)$ $>$, indicates greater than; $F$, indicate degrees Fahrenheit. Site: 1 , Sunniland; 2, Forty-Mile Bend; 3, Felda; 4, West Felda; 7, Bear Island; 9, Lehigh Park. Remarks: $8 / \mathrm{cm}^{3}$, gram per cubic centimeter; PL, private laboratory; SDS, saltwater disposal system; USBM, U.S. Bureau of Mines; USGS, U.S. Goological Survey]
\end{abstract}

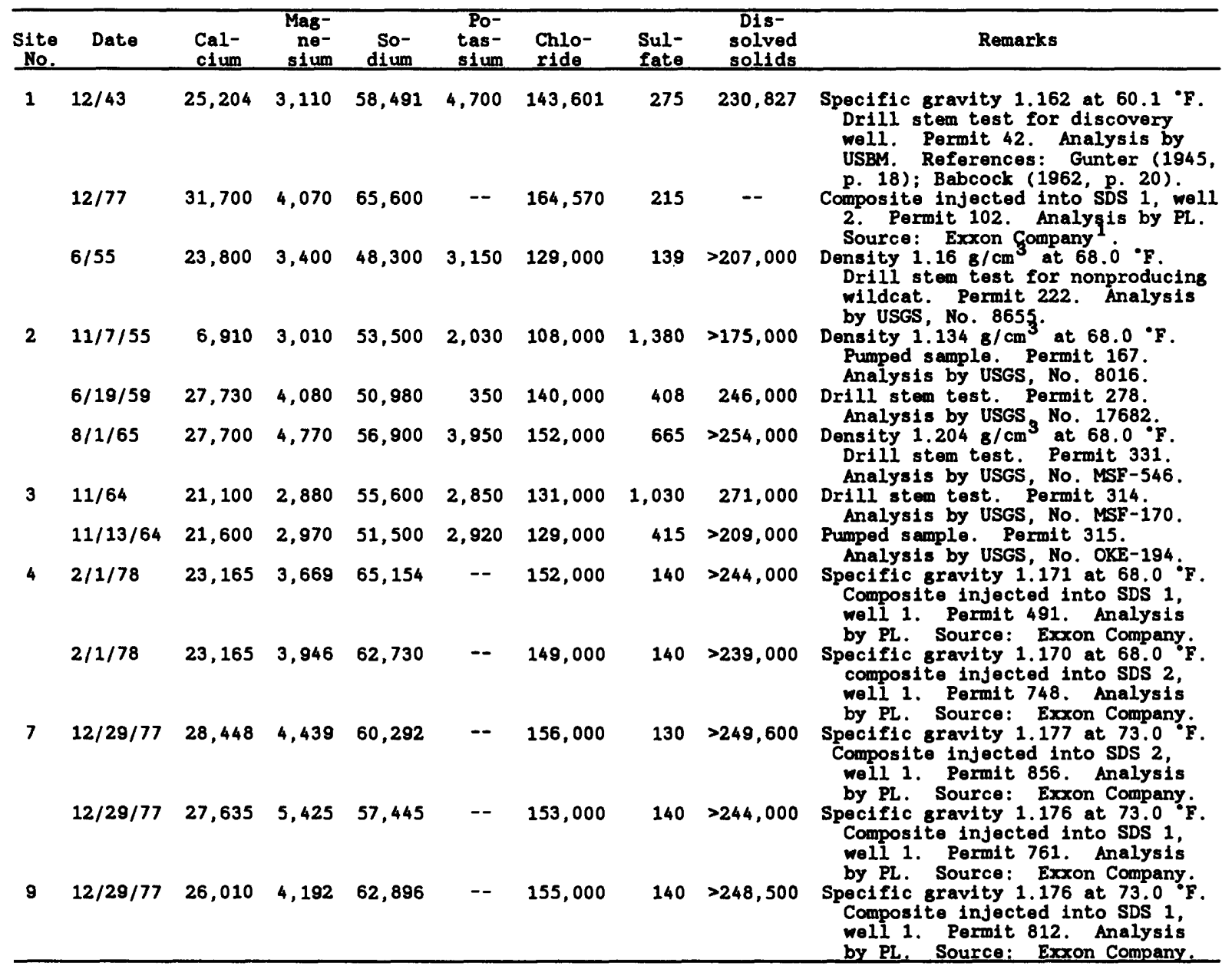

${ }^{1}$ Use of brand, firm, or trade names in this report is for identification purposes only and does not constitute endorsement by the U.S. Goological Survey.

Next is the field (fig. 5, site 1), which yielded about 18 million bbl of oil and about 51.9 million bbl of brine during 1943-83. During 1943-66, the ratio of brine to oil was relatively stable as production was mostly from the field shown as site 1 in figure 5. Subsequent oil production at site 4 resulted in significantly greater amounts of brine and, in 1971, oil production leveled off while brine production continued to increase exponentially (fig. 6). Ultimately, oil production began to decline in 1978, and brine production continued to rise. The brine-to-oil ratio in 1983 was 6.4 to 1.0 compared to a unit ratio in 1964.

Some of the produced brine was used to repressure the oil-producing zone during 196683 to enhance oil recovery. This process is called "waterflooding" or "secondary recovery" and generally involves injection of the brine back into an abandoned oil well. About 23.6 million bbl 


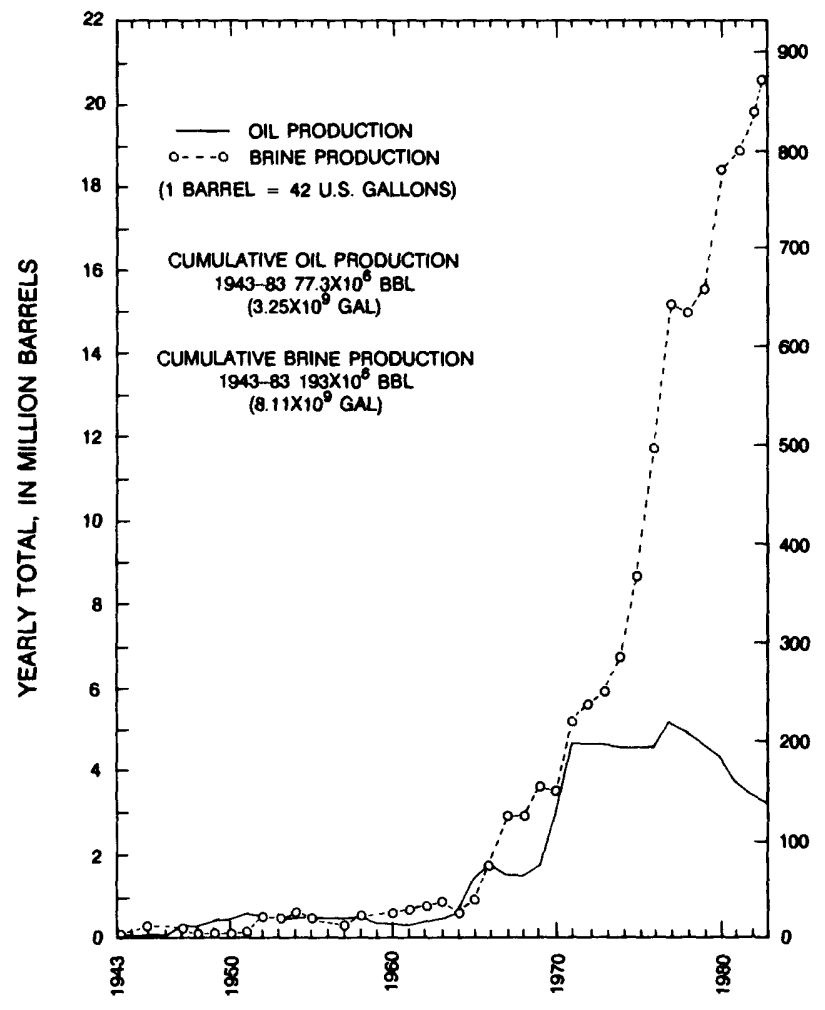

Figure 6. - Annual brine and oil production for south Florida oil fields, 1943-83.

(about $991 \mathrm{Mgal}$ ) of brine were reinjected into the producing zone for water flooding.

A summary of brine production by oil field is presented in table 2. During 1943-83, about 193.2 million bbl (about 8.1 billion gallons) of brine were produced, of which about 169.6 million bbl (about 7.1 billion gallons) were injected into the Boulder Zone (Lower Floridan aquifer), and about 23.6 million bbl (about 1.0 billion gallons) were injected back into the oil-producing zone.

Figure 7 shows the hydrogeology and construction details of typical class II oil-field brine disposal wells at two oil fields (sites 12 and 1 ). The injection well at site 2 was constructed since establishment of the UIC rules and includes current design criteria. The injection well at site 1 is a converted oil-production well with a cement plug in the lower confining unit of the Floridan aquifer system. Both wells, however, inject brine through perforations into the Boulder Zone (Lower
Floridan aquifer). The main difference between the injection wells is that the injection well at site 12 has two strings of casing that extend from land surface to the middle confining unit of the Floridan aquifer system, whereas the well at site 1 has only one string of casing to protect brackish ground water in the Upper Floridan aquifer.

\section{Municipal and Industrial Liquid Wastes}

The practice of injecting municipal and industrial liquid wastes through injection wells into the Floridan aquifer system is common in the southeastern part of the Florida Peninsula (fig. 5). The start of the injection of treated municipal wastewater and industrial liquid wastes was mentioned previously in the report. In both cases, the liquid wastes were injected into brackish waterbearing zones of the Upper Floridan aquifer because the then existing criteria for injection required only that the receiving rocks contain water having a chloride concentration of at least $1,500 \mathrm{mg} / \mathrm{L}$. Problems ultimately developed with the operation of both systems. In the wastewatertreatment plant system (site 14), the low transmissivity of the aquifer and high suspended solids in the injectant caused frequent plugging of the wellbore and excessive injection pressure (McKenzie and Irwin, 1984). In the furfural plant system (site 15), the hot acid waste migrated upward from the lower part of the Floridan aquifer system to appear in a monitored zone near the top of the aquifer (Kaufman and McKenzie, 1975; McKenzie, 1976; and Vecchioli and others, 1979).

The practice of deep-well injection became increasingly attractive in 1969 when a test injection well drilled at a wastewater-treatment plant (fig. 5, site 16) tapped the highly transmissive saltwater-filled Boulder Zone of the Lower Floridan aquifer. An evaluation of the natural water-level fluctuations in the well by Meyer (1974) suggested that the transmissivity of the Boulder Zone was about $3.2 \times 10^{6} \mathrm{ft}^{2} / \mathrm{d}$; however, a later pumping test at a wastewater-treatment plant (fig. 5, site 22) suggested that the transmissivity was about $2.5 \times 10^{7} \mathrm{ft}^{2} / \mathrm{d}$ (Singh and others, 1983). The success of the injection well at site 16 soon led to rapid exploitation of the Boulder Zone as a receptacle for nonhazardous municipal and industrial liquid wastes. 
Table 2. --Sumary of brine production and disposal for oll fields in south Florida, 1943-83

[Site: 1, Sunniland; 2, Forty-Mile Bend; 3, Felda; 4, West Felda; 5, Lake Trafford; 6, Lehigh Acres; 7 , Bear Island; 8, Seminole; 9, Lehigh Park; 10. Baxter Island; 11, Mid Felda; 12, Raccoon Point; 13, Townsend Canal. See figure 2 for site location. Site 6 was included in site 4 in 1975. Operator: C/G, Commonwealth/Gulf; NRM, Natural Resources Management. Kanaba was formerly owned by Mobil. Number of injection wells: B, Boulder Zone; P, Paleocene or older rocks; S, Sunniland Zone in Lower Cretaceous limestone. Volume of brine shown in barrels. Total in parentheses is shown in million gallons]

\begin{tabular}{|c|c|c|c|c|c|c|}
\hline Site & Operator & Period & $\begin{array}{c}\text { Brine } \\
\text { production }\end{array}$ & $\begin{array}{l}\text { Number } \\
\text { of in- } \\
\text { jection } \\
\text { rells }\end{array}$ & $\begin{array}{l}\text { Brine } \\
\text { Boulder } \\
\text { Zone }\end{array}$ & $\begin{array}{c}\text { Alsposal } \\
\text { Sunniland } \\
\text { Zone }\end{array}$ \\
\hline 1 & Exxon & $1943-73$ & $51,879,210$ & 3B & $51,879,210$ & 0 \\
\hline 2 & $\mathrm{C} / \mathrm{G}$ & $1954-55$ & 98,700 & -- & 98,700 & 0 \\
\hline 3 & Sun & $1964-83$ & $29,963,400$ & 18,95 & $13,862,112$ & $16,101,288$ \\
\hline 4 & Sun/Exxon & $1966-83$ & $72,722,755$ & $3 B, 1 S$ & $69,428,463$ & $3,294,292$ \\
\hline 5 & Kanaba & $1969-83$ & 0 & -- & 0 & 0 \\
\hline 6 & Exxon & $1970-75$ & $1,118,625$ & -- & $1,118,625$ & 0 \\
\hline 7 & Exxon & $1972-83$ & $18,369,565$ & $2 B, 8 S$ & $14,215,772$ & $4,153,793$ \\
\hline 8 & Weiner/Kanaba & $1973-78$ & 289,106 & -- & 289,106 & 0 \\
\hline 9 & Exxon & $1974-83$ & $17,658,580$ & 2B & $17,658,580$ & 0 \\
\hline 10 & Exxon & $1977-78$ & 19,485 & -- & 19,485 & 0 \\
\hline 11 & Burns & $1977-83$ & $1,000,222$ & 1B & $1,000,222$ & 0 \\
\hline 12 & Exxon & $1977-83$ & 13,880 & 18 & 13,800 & 0 \\
\hline 13 & NRM & $1982-83$ & 60,396 & $1 P$ & 0 & 160,396 \\
\hline & & $\begin{array}{r}193,193,924 \\
(8,114)\end{array}$ & & $\begin{array}{r}169,584,155 \\
(7,122)\end{array}$ & $\begin{array}{r}23,609,769 \\
(922)\end{array}$ \\
\hline
\end{tabular}

1 Injection occurs below the Boulder Zone in the open hole between 3,835 and 11,074 feet.

During 1959-69, the volume of liquid wastes injected into the Floridan aquifer system increased gradually from 98 to $340.8 \mathrm{Mgal} / \mathrm{yr}$ (fig. 8 , table 3). In 1971, the volume of liquid wastes injected began to increase exponentially and, in 1983 , it reached about $26.8 \mathrm{billion}$ gal/yr. The total amount injected for the 25-year period (195983) was about 112.1 billion gallons. Of that, 4.1 billion gallons were industrial liquid waste (sites 15 and 20), and 108 billion gallons were treated municipal wastewater.
The injected industrial liquid waste at site 15 chiefly is acetic acid, a byproduct from the production of furfural. Neutralization of the acid waste occurs in the receiving zone by dissolution of the carbonate rocks and release of carbon dioxide. High concentrations of biogenic hydrogen sulfide and methane also result from reactions in the receiving zone. Characteristics of the injected industrial liquid waste (site 15) are compared with those for the local water supply and the native ground water in the Boulder Zone in table 4. 


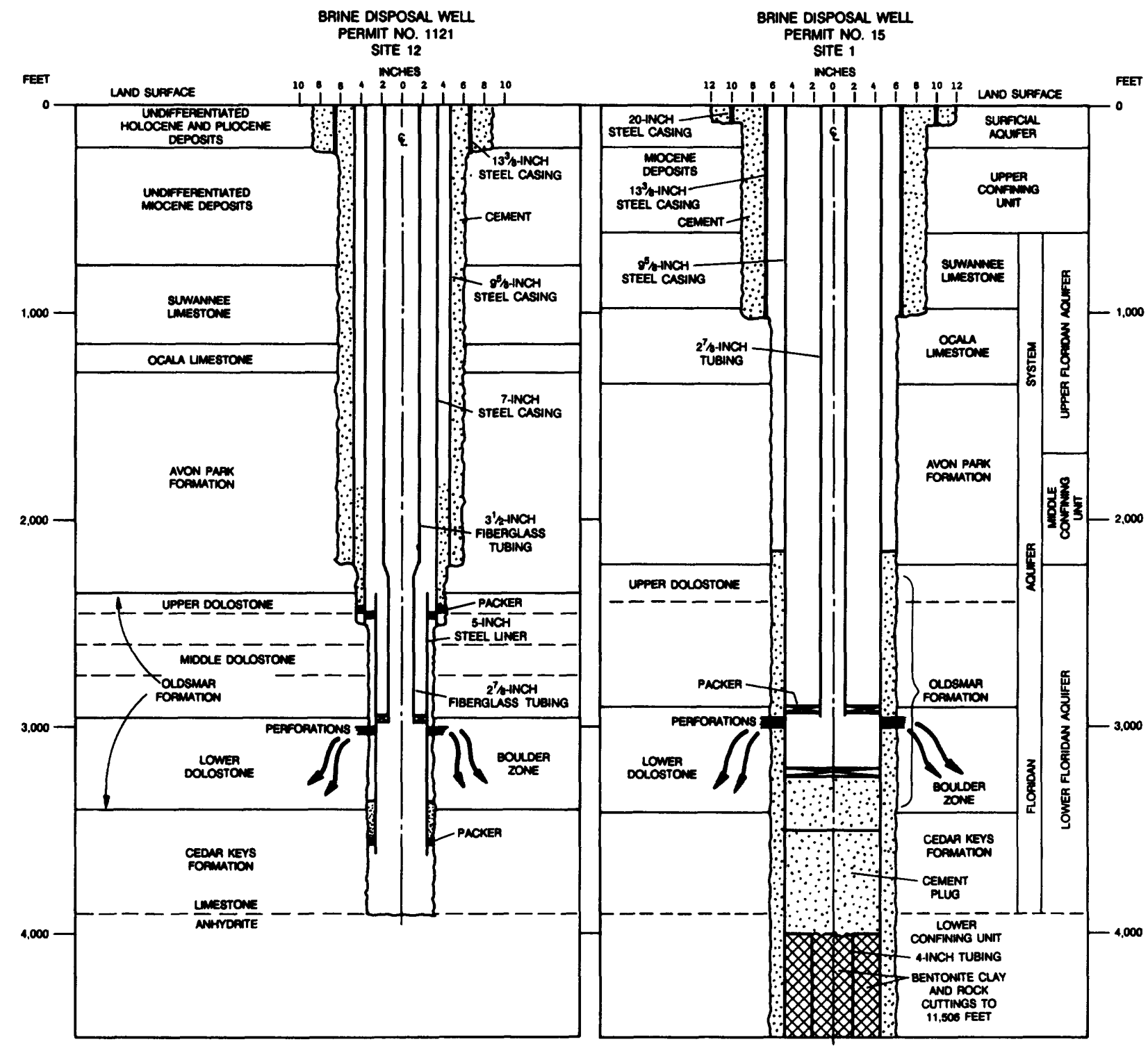

Figure 7.-Hydrogeology and typical construction of oil-field brine disposal wells.

At site 20, the industrial liquid waste is caustic (chiefly aluminum hydroxide and sodium chloride), a byproduct from the production of pectin. Analyses of the injectant from site 20 were unavailable.
The injected municipal liquid waste is secondary-treated wastewater; that is, wastewater that has had at least 90 percent of the suspended solids and biochemical oxygen demand removed by treatment. The characteristics of the treated wastewater vary from plant to plant, but the 
Table 3.-- Summary of municipal and industrial infection of liquid wastes in south Florida, 1959-83

[Amounts shown in million gallons. Amounts estimated, except from 1969 through 1974. Site: 14, Collier Manor; 15, Quaker Oats; 16, Sunset Park; 17, Kendalo Lakes;

18, Margate; 19, West Paim Beach; 20, Bercules; 21, Stuart; 22, Miami-Dade Water

and Sewer Authority South District; 23, Port St. Lucie South Port]

\begin{tabular}{|c|c|c|c|c|c|c|c|c|c|c|c|c|}
\hline \multirow{2}{*}{ Year } & \multicolumn{10}{|c|}{ Site } & \multirow{2}{*}{$\begin{array}{l}\text { Yoarly } \\
\text { total }\end{array}$} & \multirow{2}{*}{$\begin{array}{c}\text { Cumula- } \\
\text { tive }\end{array}$} \\
\hline & 14 & 15 & 16 & 17 & 18 & 19 & 20 & 21 & 22 & 23 & & \\
\hline 1959 & 98 & & & & & & & & & & 98 & 98 \\
\hline 1960 & 182 & & & & & & & & & & 182 & 280 \\
\hline 1961 & 182 & & & & & & & & & & 182 & 462 \\
\hline 1962 & 182 & & & & & & & & & & 182 & 644 \\
\hline 1963 & 182 & & & & & & & & & & 182 & 826 \\
\hline 1964 & 218 & & & & & & & & & & 219 & 1,045 \\
\hline 1965 & 219 & & & & & & & & & & 219 & 1,264 \\
\hline 1966 & 219 & 2.0 & & & & & & & & & 221 & 1,485 \\
\hline 1967 & 182 & 45.4 & & & & & & & & & 227.4 & $1,712.4$ \\
\hline 1968 & 219 & 104.6 & & & & & & & & & 323.6 & $2,036.0$ \\
\hline 1969 & 219 & 121.8 & & & & & & & & & 340.8 & $2,376.8$ \\
\hline 1970 & 265 & 200.6 & & & & & & & & & 465.6 & $2,842.4$ \\
\hline 1971 & 223 & 213.4 & 577.0 & & & & & & & & $1,013.4$ & $3,855.8$ \\
\hline 1972 & 248 & 246.5 & $1,046.0$ & & & & & & & & $1,540.5$ & $5,396.3$ \\
\hline 1973 & 293 & 307.5 & $1,275.0$ & 179.5 & & & & & & & $2,055.0$ & $7,451.3$ \\
\hline 1974 & 259 & 284.3 & $1,341.0$ & 483.9 & 570.6 & & & & & & $2,938.8$ & $10,390.1$ \\
\hline 1975 & 10 & 311.1 & $1,537.0$ & 582.3 & $1,299.4$ & & & & & & $3,739.8$ & $14,129.9$ \\
\hline 1976 & & 317.6 & $1,732.0$ & 531.4 & $1,284.0$ & & & & & & $3,865.0$ & $17,994.9$ \\
\hline 1977 & & 157.6 & $1,715.5$ & 646.8 & $1,415.1$ & 175.7 & & & & & $4,110.7$ & $22,105.6$ \\
\hline 1978 & & 187.8 & $1,734.8$ & 902.1 & $1,671.3$ & $4,253.3$ & & & & & $8,749.3$ & $30,854.9$ \\
\hline 1979 & & 272.1 & $1,957.7$ & $1,134.5$ & $1,816.6$ & $5,673.7$ & 0.2 & & & & $10,854.8$ & $41,709.7$ \\
\hline 1980 & & 375.6 & $1,723.5$ & $1,006.5$ & $1,756.7$ & $8,531.5$ & 20.4 & & & & $13,414.2$ & $55,123.9$ \\
\hline 1981 & & 358.4 & $1,754.8$ & $1,277.9$ & $1,850.6$ & $8,910.2$ & 44.2 & & & & $14,196.1$ & $69,320.0$ \\
\hline 1982 & & 201.3 & $1,856.0$ & $1,022.0$ & $1,993.6$ & $10,639.3$ & 66.8 & 81.2 & & & $15,860.2$ & $85,180.2$ \\
\hline 1983 & & 161.1 & 139.3 & 82.3 & $2,001.3$ & $11,125.1$ & 55.3 & 742.5 & $12,376.9$ & 144.6 & $26,828,4$ & $112,008.6$ \\
\hline Total & 3,401 & $3,868.7$ & $18,389.6$ & $7,849.2$ & $15,659.2$ & $49,308.8$ & 186.9 & 823.7 & $12,376.9$ & 144.6 & $112,008.6$ & \\
\hline
\end{tabular}


Table 4.--Selected water-quality characteristics of injectant. local water supply, and native ground water in the Boulder Zone at sites 15 and 19 in Palm Beach County and at site 22 in Dade County

[Site: 15, Quaker Oats; 19, West Palm Beach regional wastewater treatment plant; 22, Miami-Dade South District wastewater treatment plant. Concentrations shown in milligrams per ilter, except for specific conductance which is in microsiemens per centimeter and temperature which is in degrees Celsius. Analyses by U.S. Geological Survey, except where noted. > = greater than; < = less than; ${ }^{\circ} \mathrm{C}=$ degrees Celsius. Temperature of injectant at site 15 is reduced to about $50{ }^{\circ} \mathrm{C}$ before injection]

\begin{tabular}{|c|c|c|c|c|c|c|c|c|c|}
\hline \multirow[b]{2}{*}{ Characteristic } & \multicolumn{3}{|c|}{ Stte $15^{1}$} & \multicolumn{3}{|c|}{ Site $19^{2}$} & \multicolumn{3}{|c|}{ Site $22^{3}$} \\
\hline & $\begin{array}{c}\text { Injec- } \\
\text { tant }\end{array}$ & $\begin{array}{l}\text { Water } \\
\text { supply }\end{array}$ & $\begin{array}{l}\text { Ground } \\
\text { water } \\
\text { in the } \\
\text { Boulder } \\
\text { Zone }\end{array}$ & $\begin{array}{c}\text { Injec- } \\
\text { tant }\end{array}$ & $\begin{array}{l}\text { Water } \\
\text { supply }\end{array}$ & $\begin{array}{l}\text { Ground } \\
\text { water } \\
\text { In the } \\
\text { Boulder } \\
\text { Zone }\end{array}$ & $\underset{\text { Injec- }}{\text { Int }}$ & $\begin{array}{l}\text { Water } \\
\text { supply }\end{array}$ & $\begin{array}{l}\text { Ground } \\
\text { water } \\
\text { in the } \\
\text { Boulder } \\
\text { Zone }\end{array}$ \\
\hline
\end{tabular}

\begin{tabular}{|c|c|c|c|c|c|c|c|c|c|}
\hline Acidity, as $\mathrm{H}^{+}$ & 208 & 0 & 0 & -- & -- & -- & -- & 0 & 0 \\
\hline B1carbonate $\left(\mathrm{HCO}_{3}\right)$ & 0 & 150 & 200 & 120 & 150 & 180 & - & 260 & 146 \\
\hline Chloride (C1) & 160 & 99 & 19,000 & 240 & 78 & 21,000 & 65 & 25 & 19,000 \\
\hline $\begin{array}{l}\text { Dissolved solids } \\
\quad\left(\text { residue at } 180^{\circ} \mathrm{C}\right)\end{array}$ & 9,720 & $>380$ & 36,100 & 1,060 & 330 & 37,400 & 360 & 322 & 37,900 \\
\hline Magnesium (Mg) & 63 & 21 & 1,300 & 16 & 8.9 & 1,300 & -- & 3.2 & 1,200 \\
\hline $\mathrm{pH}$ (units) & 2.9 & 8.6 & 7.9 & 6.7 & 8.3 & 7.6 & 6.0 & 7.5 & 7.1 \\
\hline Potassium (K) & 310 & 5 & 410 & 15 & 3.1 & 450 & -- & 1.7 & 200 \\
\hline Sodium (Na) & 110 & 60 & 12,000 & 160 & 45 & 12,000 & -- & 16 & 11,000 \\
\hline Specific conductance & 2,400 & 700 & 51,500 & 1,220 & 550 & $>50,000$ & 700 & 540 & 52,900 \\
\hline Sulfate $\left(\mathrm{SO}_{4}\right)$ & 290 & 66 & 2,400 & 110 & 33 & 2,800 & -- & 28 & 2,600 \\
\hline $\begin{array}{l}\text { Suspended solids } \\
\quad\left(\text { residue at } 110^{\circ} \mathrm{C}\right)\end{array}$ & 1,500 & -- & -- & 12 & -- & 43 & -- & -- & -- \\
\hline Temperature & 75.0 & $\begin{array}{r}26.5 \\
\text { Lected nv }\end{array}$ & rients an & $\begin{array}{r}26.0 \\
\text { d related }\end{array}$ & $\begin{array}{c}26.5 \\
\text { characte }\end{array}$ & cistics & 31.0 & 28.0 & $<19.0$ \\
\hline Carbon, total organic & 7,500 & 20 & -- & 15 & -- & 8.2 & 7.65 & 2.0 & 3.9 \\
\hline Nitrogen, ammonia as $N$ & 19 & .03 & -- & .03 & -- & $<.01$ & 17.5 & .01 & .12 \\
\hline Nitrogen, total as $N$ & 138 & 1.6 & -- & 1.6 & $>.02$ & .00 & 18.6 & .36 & .24 \\
\hline Phosphorus, total as $P$ & 47 & .02 & -- & .08 & -- & .02 & 1.56 & $<.01$ & $<.01$ \\
\hline
\end{tabular}

Major inorganics and related physical characteristics

${ }^{1}$ Sample of plant effluent (injectant of industrial wastewater) was collected on July 8 , 1974; sample of water supply was collected at North New River Canal below BGS-4 and S-2 on Apri1 18, 1974; sample of native ground water (Boulder Zone) was collected from injection well 3 at 3,130 feet on June 29, 1976.

2 Sample of treated effluent (injectant of secondary-treated wastewater) was collected on April 18, 1978 ; sample of raw surface-water supply (Clear Lake) was collected on May 9, 1979; sample of native ground water (Boulder Zone) was collected from injection well 2 on May 30, 1972, density was 1.022 grams per milliliter at $20.0^{\circ} \mathrm{C}$, and hydrogen sulfide was 2.4 mililgrams per 1iter.

${ }^{3}$ Sample of treated effluent (injectant of secondary-treated wastewater) was collected on August 14 , 1984, and analyses was by the Miami-Dade Water and Sewer Authority; sample of raw water supply from the Biscayne aquifer was collected on June 6, 1975; sample of native ground water (Boulder Zone) was collected from monitor we11 BZ-1 between depth of 2,689 and 2,960 feet on October 22, 1981, and sample contained high metal concentrations because of pipe erosion. 


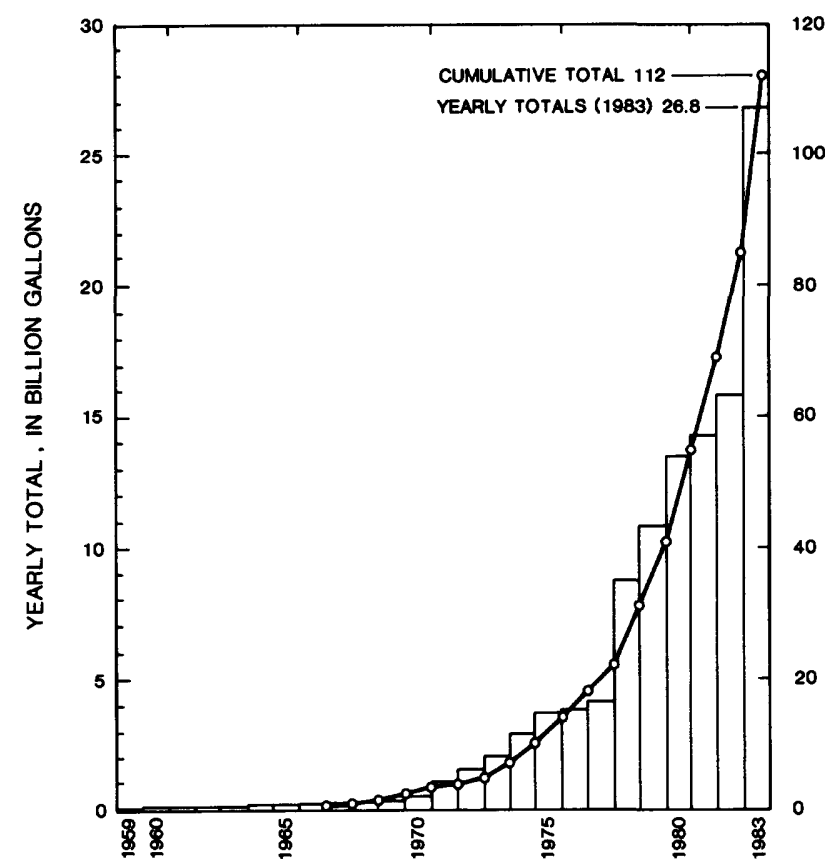

Figure 8.-Annual and cumulative volumes of municipal and industrial liquid-waste injection, 1959-83. wastewaters are distinguished from local water supply by high concentrations of nutrients. The characteristics of the injected wastewater at two wastewater-treatment plants (sites 19 and 22) are compared with those for local water supply and native ground water in the Boulder Zone in table 4.

Injection into the brackish water-bearing zones of the Upper Floridan aquifer occurred only at sites 14 and 15). The combined amount for both sites during $1959-75$ was about 5.0 billion gallons.

Injection into the middle confining unit and perhaps the upper unit of the Lower Floridan aquifer occurred only at site 15 where about 656.7 Mgal were injected during 1972-75.

Injection into the Boulder Zone of the Lower Floridan aquifer occurred at the eight remaining sites during $1971-83$ and at site 15 during $1977-$ 83. The total amount injected into the Boulder Zone during 1971-83 was about 106.4 billion gallons.

Injection rates have increased exponentially since 1971 when the injection well at site 16 became operational and injection was directed to the Boulder Zone. In 1983, the rate was about 73.5 $\mathrm{Mgal} / \mathrm{d}$, and the estimated rate for 1984 was 112 $\mathrm{Mgal} / \mathrm{d}$ (table 5).

In 1983, two injection wells (fig. 5 , sites 16 and 17) were removed from service because of small

Table 5.--Average rate of municipal and industrial injection, 1959-84

[In million gallons per day; rate for 1984 is estimated]

\begin{tabular}{rrrrrrrrr}
\hline Year & Rate & Year & Rate & Year & Rate & Year & Rate \\
\hline 1959 & 0.268 & 1966 & 0.605 & 1973 & 5.630 & 1980 & 36.751 \\
1960 & .499 & 1967 & .623 & 1974 & 8.052 & 1981 & 38.894 \\
1961 & .499 & 1968 & .887 & 1975 & 10.520 & 1982 & 43.453 \\
1962 & .499 & 1969 & .934 & 1976 & 10.589 & 1983 & 73.502 \\
1963 & .499 & 1970 & 1.276 & 1977 & 11.262 & 1984 & 112 \\
1964 & .600 & 1971 & 2.776 & 1978 & 23.971 & & \\
1965 & .600 & 1972 & 4.221 & 1979 & 29.739 & & \\
\hline
\end{tabular}




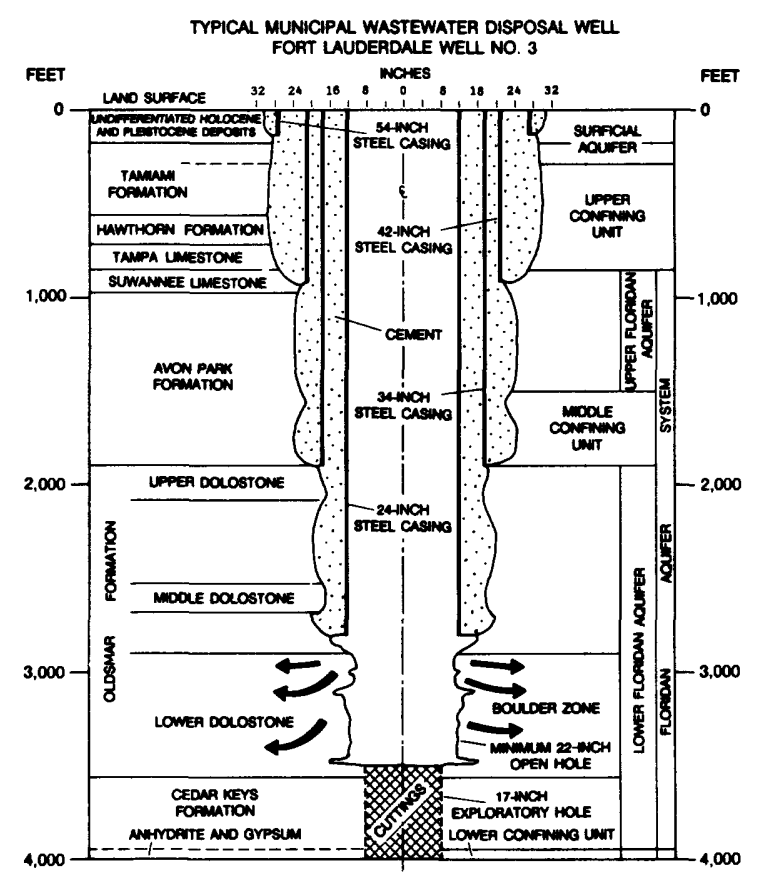

Figure 9.-Hydrogeology and typical construction characteristics of municipal wastewater-disposal well.

leaks in uncemented (conductor) inner casings, and the effluent from the plant was directed to other treatment facilities of the Miami-Dade Water and Sewer Authority. Also, in 1983, a small leak was detected in the uncemented inner casing of a third injection well (fig. 5 , site 18), and construction of a replacement well was required by the Florida Department of Environmental Regulation before remedial work could be performed on the leaking well. Despite these minor problems, which have been resolved by the enforcement of the UIC rules, the outlook for class I deep-well injection in south Florida is for continued expansion. The outlook, however, should include caution because the injected liquid wastes will ultimately become part of the regional ground-water circulation system. The injected waste, thus, will move with the hypothesized inland and upward flow of seawater from the Straits of Florida through the Boulder Zone of the Lower Floridan aquifer.

Typical construction characteristics of nontoxic class I municipal and industrial liquid-waste disposal wells are shown in figures 9 and 10 along

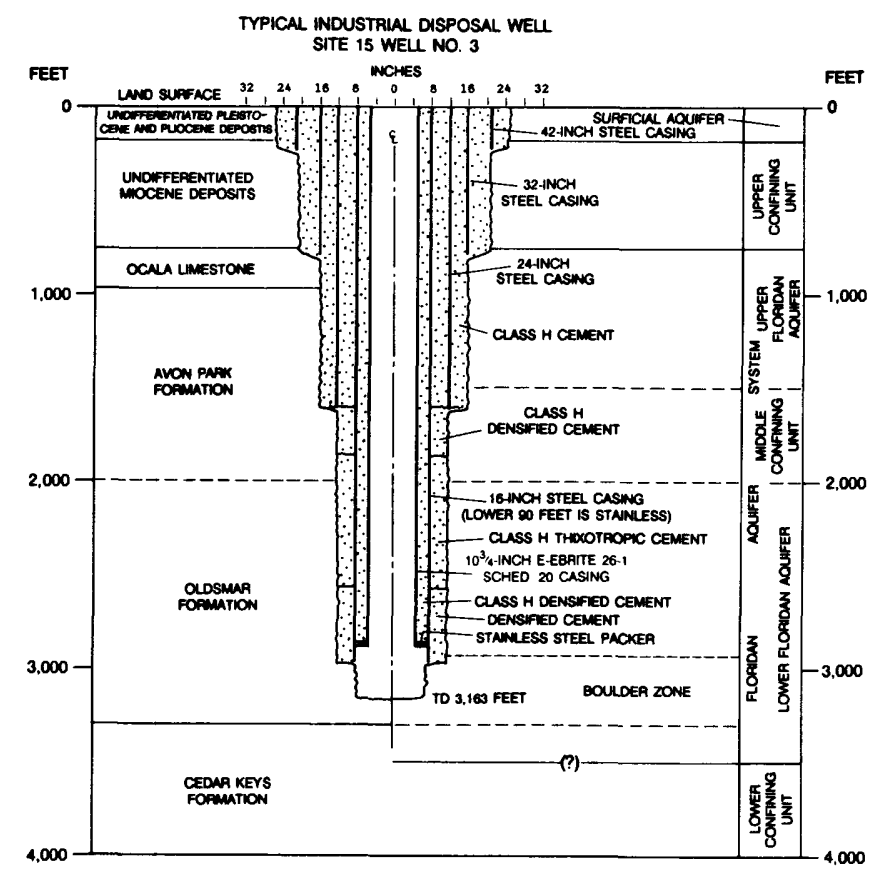

Figure 10.-Hydrologeology and typical construction charactersitics of an industrial liquid-waste disposal well.

with the local hydrogeology. The construction of the municipal liquid-waste disposal well (fig. 9) is based on that for well 3 at the City of Fort Lauderdale's Port Everglades wastewater-treatment plant (fig. 5, site 9). The well is constructed with telescoping steel casings to protect potential drinking water resources in the surficial aquifer and the Upper Floridan aquifer. The casings are cemented in place, from top to bottom, with special sulfate-resistant cement. The steel inner (conductor) casing is $\mathbf{2 4}$ inches in diameter and is 0.5 -inch thick. The well has a minimum injection capacity of $15 \mathrm{Mgal} / \mathrm{d}$.

The construction of the industrial liquid-waste disposal well is based on that for well 3 at the furfural plant (fig. 5, site 15). The well is also constructed with several steel casings that are cemented in place with special cement to resist heat and corrosion and to protect potential drinking water resources. The inner (conductor) casing is a special alloy which is acid and heat resistant. Not shown in figures 9 and 10 are monitor wells, which are located nearby to detect leaks and upward migrating wastes. 


\section{Freshwater}

Subsurface storage of freshwater in the Floridan aquifer system as an alternative to surface storage has become increasingly attractive to water managers in south Florida as urbanization and population growth have placed increasing demands on the water supply. The advantages of the subsurface storage concept are that subsurface space is free, water loss by evapotranspiration is nonexistent, and the site may be located at the point of greatest need, provided hydrogeologic conditions are favorable. The concept is particularly desirable in south Florida where real estate has become very expensive, the availability of water is seasonal, and underlying artesian aquifers in the intermediate (Miocene) aquifer system and the Floridan aquifer system contain nonpotable saline ground water.

The source of freshwater for injection would be whatever surplus is available within the surfacewater storage system or the surficial aquifer system during the annual wet season. On an annual basis, the surplus freshwater would be injected through class $\mathrm{V}$ injection wells into suitable artesian aquifers during the wet season, stored for a short period (perhaps 3 to 6 months), then withdrawn as needed during the dry season, hence, the term "cyclic injection-storagerecovery" that is used in this report. The success of a cycle is the recovery efficiency which is defined as the volume of freshwater recovered before it fails to meet a prescribed chemical standard, expressed as a percentage of the volume of freshwater that was injected. Pilot studies to date in south Florida have assumed the chemical standard established by the U.S. Environmental Protection Agency (EPA) for chloride concentration $(250 \mathrm{mg} / \mathrm{L})$ of public water supply (U.S. Environmental Protection Agency, 1983. Other criteria may be used depending on the particular use of the recovered water. For example, a higher chloride standard could be used if the recovered water were mixed with surface water to yield a blend that would meet drinking water standards.

Theoretical and pilot-operational studies to date indicate that the recovery efficiency usually improves with successive cycles, provided that recovery ceases when the recovered water reaches the standard, and that the storage period is suffi- ciently short to prevent significant migration of the injectant away from the point of recovery.

Pilot studies have been conducted at four sites (fig. 5) in south Florida with varying degrees of success (Merritt and others, 1983; Wedderburn and Knapp, 1983). Also, data on the recovery of injected wastewater (freshwater) from class I injection wells during repairs, testing, and abandonment have yielded valuable information on the recovery efficiency (McKenzie and Irwin, 1984). Aspects of the existing pilot studies are summarized in table 6. Of the four studies, three (fig. 5 , sites 24,25 , and 27 ) involved injection into water-bearing zones of the Upper Floridan aquifer, and one (fig. 5, site 26) involved injection into water-bearing zones of the intermediate aquifer system. Plugging of the wellbore by suspended solids in the injectant was a significant problem in all four studies.

At site 24 in Palm Beach County (table 6), injection was chiefly into water-bearing zones of the Ocala Limestone and Avon Park Formation (units of the Upper Floridan aquifer). The study involved four injection-storage-recovery cycles (J.J. Plappert, Florida Department of Environmental Regulation, written commun., 1977). Recovery efficiencies ranged from 0 to 35.2 percent. The transmissivity of the injection zone(s) probably is on the order of 10,000 to $20,000 \mathrm{ft}^{2} / \mathrm{d}$ although data are lacking to support that assumption. The injection zones are apparently associated with zones of dissolution occurring at or near unconformities that separate formations.

At site 25 in Dade County (table 6), injection of freshwater chiefly was into water-bearing zones of the Suwannee Limestone although the injection well tapped parts of the Tampa Limestone and Avon Park Formation (all units of the Upper Floridan aquifer). The study involved three injection-storage-recovery cycles. Recovery efficiencies ranged from 32.9 to 47.8 percent. A decline in the efficiency was recorded for the third cycle, which probably was related to migration of the injectant downgradient from the injectionrecovery well during the 181 days of storage. The transmissivity of the injection zone(s) is 11,000 $\mathrm{ft}^{2} / \mathrm{d}$. The results of the tests at this site were the basis for theoretical studies that used a mathematical model to evaluate the effects of varying 

Table 6. - - Results of injection, storage, and recovery tests at sites 24 (Palm Beach County,
$\quad 1975-76$ ) $1982-83)$

[Site 24, analyses by Florida Department of Natural Resources and Florida Department of Environmental Regulation (FDER) (from J.J. Plappert, FDER, written commun., 1977; site 25, analyses by U.S. Geological Survey (USGS); site 26, analyses by USGS (from Fitzpatrick, 1986); site 27, analyses by South Florida Water Management District (from Wedderburn and Knapp, 1983). Open hole: site 24, 990-1,280 feet (Ocala Limestone and Avon Park Formation; site 25, 955-1,055 feet (Tampa Limestone and Suwannee Limestone and Avon Park Formation); site 26, 447-600 feet (1imestone of the Bawthorn Formation); site 27, 600-775 feet (1imestone of the Hawthorn Formation, Ocala Limestone, and Avon Park Formation)]

\begin{tabular}{|c|c|c|c|c|c|c|c|}
\hline Site & Cycle & $\begin{array}{l}\text { Quantity } \\
\text { injected } \\
\text { (million } \\
\text { gallons) }\end{array}$ & $\begin{array}{l}\text { Storage } \\
\text { period } \\
\text { (days) }\end{array}$ & $\begin{array}{l}\text { Quantity of } \\
\text { potable watpr } \\
\text { recovered } \\
\text { (million } \\
\text { gallons) }\end{array}$ & $\begin{array}{l}\text { Recovery } 2 \\
\text { efficiency } \\
\text { (percent) }\end{array}$ & $\begin{array}{c}\text { Injection } \\
\text { rate } \\
\text { (gallons } \\
\text { per minute) }\end{array}$ & $\begin{array}{c}\text { Withdrayjal } \\
\text { rate } \\
\text { (gallons } \\
\text { per minute) }\end{array}$ \\
\hline 24 & $\begin{array}{l}1 \\
2 \\
3 \\
4\end{array}$ & $\begin{array}{l}20.5 \\
100 \\
306 \\
102\end{array}$ & $\begin{array}{r}15 \\
30 \\
30 \\
120\end{array}$ & $\begin{array}{c}0 \\
4.7 \\
55.5 \\
36.1\end{array}$ & $\begin{array}{r}0 \\
4.7 \\
18.0 \\
35.2\end{array}$ & $\begin{array}{l}2,000 \\
2,000 \\
2,000 \\
2,000\end{array}$ & $\begin{array}{l}1,000 \\
1,000 \\
1,000 \\
1,000\end{array}$ \\
\hline 25 & $\begin{array}{l}1 \\
2 \\
3\end{array}$ & $\begin{array}{l}41.9 \\
85 \\
208\end{array}$ & $\begin{array}{r}2 \\
54 \\
181\end{array}$ & $\begin{array}{l}13.8 \\
40.7 \\
80.1\end{array}$ & $\begin{array}{l}32.9 \\
47.8 \\
38.5\end{array}$ & $\begin{array}{c}440-780 \\
854 \\
800\end{array}$ & $\begin{array}{l}330 \\
494 \\
450\end{array}$ \\
\hline 26 & $\begin{array}{l}1 \\
2 \\
3\end{array}$ & $\begin{array}{r}.571 \\
6.831 \\
29.026\end{array}$ & $\begin{array}{r}0 \\
47 \\
99\end{array}$ & $\begin{array}{r}.221 \\
.663 \\
8.819\end{array}$ & $\begin{array}{r}38.7 \\
9.7 \\
30.4\end{array}$ & $\begin{array}{c}170-350 \\
300 \\
300\end{array}$ & $\begin{array}{r}95-110 \\
165-175 \\
150\end{array}$ \\
\hline 27 & 1 & 1.488 & 37.5 & .041 & 2.76 & 331 & $140-190$ \\
\hline
\end{tabular}

- Transmissivity: site 24, unknown; site $25,11,000 \mathrm{ft}^{2} / \mathrm{d}$ (feet squared per day) (estimated by mogel simulation of weil G-3062 pumping test); site 26, 700 to $800 \mathrm{ft} / \mathrm{d} ; \mathrm{site} 27,6,000$ $f t^{2} / d$.

- Storage coefficient: site 24 , unknown; site $25,8.4 \times 10^{-5}$ (estimated by model simulation of well G-3062 pumping test); site 26 , about $1 \times 10^{-4}$; site $27,1.6 \times 10^{-4}$.

- Injected water chloride concentration: site 24, $65 \mathrm{mg} / \mathrm{L}$ (milligrams per 11ter); site 25, 65 $\mathrm{mg} / \mathrm{L}$; site 26, $60 \mathrm{mg} / \mathrm{L}$ (cycle 1), 150 to $350 \mathrm{mg} / \mathrm{L}$ (cycle 2) (abnormally high because of record-low flows in Caloosahatchee River source, but decreased during injection), 80 to 100 $\mathrm{mg} / \mathrm{L}$ (finished water), $60 \mathrm{mg} / \mathrm{L}$ (raw water) (cycle 3); site 27, $200 \mathrm{mg} / \mathrm{L}$.

- Resident water chloride concentration: site 24, 1,980 mg/L; site 25, 1,200 mg/L (multilevel composite, range from 800 to $2,000 \mathrm{mg} / \mathrm{L}$ ); site $26,550 \mathrm{mg} / \mathrm{L}$; site $27,1,000 \mathrm{mg} / \mathrm{L}$.

1 At site 24 recovery was terminated when the chloride concentration of the recovered water reached 250 milligrams per liter.

2 At site 26, the efficiency (9.7 percent, cycle 2) was low because of relatively high chloride concentration of injected water; the purpose was to test the well after acidification. At site 27 , recovery efficiency would have been 33 percent if the chloride concentration of the injected water had been 50 milligrams per liter.

3 At sites 25 and 26 , natural artesian flow occurs; however, at site 26 , improvement in cycle 2 is because of acidification of well.

4 Progressive decline because of wellbore plugging.

5 Estimated after loss of water because of equipment failure. 


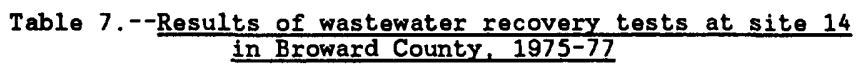

[Analysis by U.S. Geological Survey (from McKenzie and Irwin, 1984). Quantity injected, in million gallons: storage period, in days; quantity of potable water recovered, in million gallons; injection and withdrawal rates, in gallons per minute]

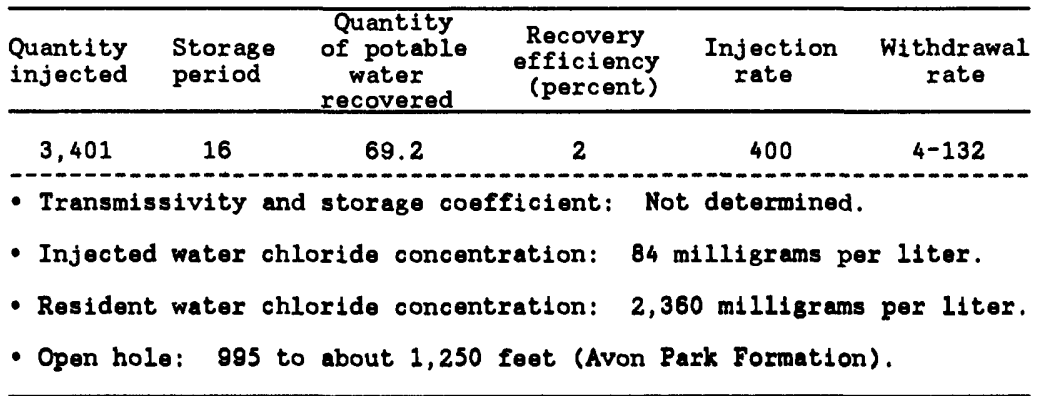

aquifer characteristics, fluid salinity, regional flow, well patterns, and operating schedules on the recovery efficiency (Merritt, 1985).

At site 26 in Lee County (table 6), injection of freshwater was into water-bearing zones in limestone of the Hawthorn Formation (unit of the intermediate aquifer system). The study involved three injection-storage-recovery cycles. Recovery efficiencies ranged from 9.7 to 38.7 percent. The efficiency of the first cycle, which had the greatest efficiency value, probably is not representative of the true efficiency because of the small amount injected and short storage period. The data for the third cycle ( 30.4 percent) probably represents the efficiency and the storage capability of the aquifer. The transmissivity of the injection zone(s) is about $750 \mathrm{ft}^{2} / \mathrm{d}$.

At site 27 in St. Lucie County (table 6), injection of freshwater chiefly was into water-bearing zones of the Ocala Limestone and Avon Park Formation of the Upper Floridan aquifer. The water-bearing zones are associated with zones of dissolution near formation contacts. The study involved one injection-storage-recovery cycle for which the recovery efficiency was only 2.76 percent. The low efficiency was because of the high chloride concentration $(200 \mathrm{mg} / \mathrm{L})$ of the injec- tant. This recovery efficiency represented a 79 percent blend of the injectant (chloride concentration of $200 \mathrm{mg} / \mathrm{L}$ ) with native ground water (chloride concentration of $1,000 \mathrm{mg} / \mathrm{L}$ ). A recovery efficiency of 33 percent would have been realized had the chloride concentration of the injectant been $50 \mathrm{mg} / \mathrm{L}$ (based on the indicated rate of mixing and the limit of $250 \mathrm{mg} / \mathrm{L}$ for chloride in drinking water). The transmissivity of the injection zone $(\mathrm{s})$ is $6,000 \mathrm{ft}^{2} / \mathrm{d}$.

During 1975-77, the U.S. Geological Survey, in cooperation with the Florida Department of Environmental Regulation, conducted a study of the quality of recovered secondary-treated wastewater from subsurface storage in the Upper Floridan aquifer at site 14 in Broward County (table 7). The injection system consisted of two wells that were in operation from 1959 to 1975. Injection ceased in January 1975 when the plant's function was transferred to the Broward County North Regional Wastewater-Treatment Plant. Recovery of the injected treated wastewater began in April 1975 and ended in March 1977, when the chloride concentration reached 250 $\mathrm{mg} / \mathrm{L}$. The recovery efficiency, based on reaching a chloride concentration of $250 \mathrm{mg} / \mathrm{L}$, was only 2 percent, which was much less than expected for 
the great volume (3.4 billion gallons) that was injected during the 16 years of operation. The transmissivity of the injection zone was not determined but probably was greater than the previously discussed freshwater storage pilot studies. Records of the construction of one injection well suggest that injection occurred to a greater depth (perhaps as deep as 1,600 feet) than previously reported. The low recovery efficiency probably is a result of higher aquifer transmissivity, higher chloride concentration (hence, higher density) of the resident water, and construction problems. As with the previous pilot studies, plugging of the wellbore by suspended solids was a significant problem.

Unpublished data collected by the Florida Department of Environmental Regulation on the anount of treated sewage recovered from abandoned injection wells at sites 16 and 17 in Dade County suggest that the recovery efficiency for wells that tap the Boulder Zone of the Lower Floridan aquifer is virtually nonexistent. The injection well at site 16 was abandoned in 1983 after 13 years of operation and after about 18.4 billion gallons of effluent was injected; the injection well at site 17, also abandoned in 1983, was operated for 11 years during which time about 7.8 billion gallons of effluent was injected. At both sites, the chloride concentration of the injectant was about $60 \mathrm{mg} / \mathrm{L}$, and the chloride concentration of the resident water was about $19,200 \mathrm{mg} / \mathrm{L}$. For both sites, the annount of treated sewage recovered before the chloride concentration exceeded $250 \mathrm{mg} / \mathrm{L}$ did not exceed $1 \mathrm{Mgal}$. The recovery tests indicate that there is no potential for recovering stored freshwater from the highly transmissive Boulder Zone.

Dissolution zones at erosional unconformities between the Suwannee Limestone and Ocala Limestone and the Avon Park Formation probably offer the best opportunity for large-scale storage of freshwater in the subsurface of south Florida. Detailed maps of the dissolution zones are unavailable, but generalized regional maps showing the configuration of the top of the middle and upper Eocene rocks are shown in Miller (1986). The surface is irregular and shows the effects of large-scale erosion at the close of the Eocene Epoch. Erosion removed the Ocala
Limestone from much of southeast Florida and exposed the underlying (older) Avon Park Formation. Zones of dissolution are prominent near this erosion surface; therefore, the maps in Miller (1986) may be used to estimate the depth at which favorable injection zones likely occur.

\section{SUMMARY}

Subsurface storage of liquids is the practice of emplacing fluids in permeable underground rocks (aquifers) by gravity flow or pressure-induced injection through wells. Regulation of the practice in Florida is the responsibility of the U.S. Environmental Protection Agency, the Florida Department of Environmental Regulation, and the Florida Department of Natural Resources.

Injection of nontoxic liquid wastes into deep, saline parts of the Floridan aquifer system as a pollution-control measure began in 1943 with injection of oil-field brine in southwest Florida. Since then, the practice has expanded rapidly, and many high-capacity municipal and industrial injection wells are now in operation in southeast Florida.

In south Florida, the Floridan aquifer system is about 3,000 feet thick and is chiefly composed of carbonate rocks that range in age from early Miocene to Paleocene. It is divided into three general hydrogeologic units: (1) the Upper Floridan aquifer, which contains brackish ground water; (2) the middle confining unit, which contains salty ground water; and (3) the Lower Floridan aquifer, which contains ground water whose chemical composition compares closely to that of seawater. Zones of high permeability occur in the Upper Floridan aquifer at the unconformable contact of the Suwannee Limestone with the Ocala Limestone and the Ocala Limestone with the Avon Park Formation. Zones of high permeability in the Lower Floridan aquifer occur in three dolostones in the Oldsmar Formation of which the lowermost, locally called the Boulder Zone, is perhaps one of the most permeable units in the world. The maximum transmissivities of the Upper and Lower Floridan aquifers probably are about $2.5 \times 10^{5} \mathrm{ft}^{2} / \mathrm{d}$ and $2.5 \times 10^{7} \mathrm{ft}^{2} / \mathrm{d}$, respectively. The porosity of both aquifers is estimated at 0.3. In southeast Florida, the salinity of the ground water in the Floridan aquifer system 
generally increases with increasing depth, whereas water temperature decreases with increasing depth. Temperatures of salty ground water in the Lower Floridan aquifer (Boulder Zone) range from about $50^{\circ} \mathrm{F}$ at Fort Lauderdale on the southeast coast to about $110^{\circ} \mathrm{F}$ near Punta Gorda on the southwest coast.

Ground-water movement in the Upper Floridan aquifer in south Florida generally is southward from the recharge areas in central Florida, and then west and east to the Gulf of Mexico and the Atlantic Ocean. Hydraulic gradients in the Upper Floridan aquifer in southeast Florida suggest that eastward-flowing, brackish ground water is actively discharging through unfilled sinkholes on the Miami Terrace as submarine springs. The middle confining umit is relatively less permeable than the Upper and Lower Floridan aquifers, and it separates the two flow systems. However, the hydraulic connection between the aquifers is inferred from the occurrence of sinkholes and fractures and from local temperatures and salinity anomalies in the Upper Floridan aquifer.

The Floridan aquifer system has been used as a receptacle for oil-field brine since 1943. During 1943 - 83, about 8.1 billion gallons of brine were produced with about 3.2 billion gallons of oil. Of the 8.1 billion gallons of brine, about 7.1 billion gallons were injected into the Floridan aquifer system. During 1959-83, about 112.1 billion gallons of nontoxic liquid waste were injected into the Floridan aquifer system by municipal wastewatertreatment systems and industry. The average rate of injection increased from about $0.3 \mathrm{Mgal} / \mathrm{d}$ in 1959 to about $73.5 \mathrm{Mgal} / \mathrm{d}$ in 1983 . In 1984, the estimated rate of injection was $112 \mathrm{Mgal} / \mathrm{d}$. Injection of nontoxic liquid waste chiefly is into the Boulder Zone of the Lower Floridan aquifer although small amounts have been injected into the Upper Floridan aquifer.

Pilot studies indicate that the Upper Floridan aquifer can be used for temporal storage of freshwater. However, storage of freshwater in the Lower Floridan aquifer is not feasible.

\section{REFERENCES CITED}

Babcock, Clarence, 1962, Florida petroleum exploration, production, and prospects: Florida Geological Survey Special Publication 9, 79 p.

Bush, P.W., 1982, Predevelopment flow in the Tertiary limestone aquifer, southeastern United States, a regional analysis from digital modeling: U.S. Geological Survey WaterResources Investigations Report 82-905, $41 \mathrm{p}$.

Fitzpatrick, D.J., 1986, Tests for injecting, storing, and recovering freshwater in a saline artesian aquifer, Lee County, Florida: U.S. Geological Survey Water-Resources Investigations Report 85-4249, 53 p.

Florida Department of Environmental Regulation, 1982, Underground injection control program: Chapter $17-28$ in Florida Administrative Code.

Garcia-Bengochea, J.I., and Vernon, R.O., 1969, Deep-well disposal of wastewaters in saline aquifers of south Florida: American Geophysical Union Meeting, Washington, D.C., April.

Gunter, Herman, 1945, Sixth biennial report of the Florida Geological Survey, biennium ending December 31, 1946: Florida Geological Survey Biennial Report 7, 22 p.

Johnston, R.H., Healy, H.G., and Hayes, L.R., 1981, Potentiometric surface of the Tertiary limestone aquifer system, southeastern United States, May 1980: U.S. Geological Survey Open-File Report 81 - 486, 1 sheet.

Kaufman, M.I., and McKenzie, D.J., 1975, Upward migration of deep-well waste injection fluids in Floridan aquifer, south Florida: U.S. Geological Survey Journal of Research, v. 3, no. 3, p. $261-271$.

Kohout, F.A., 1965, A hypothesis concerning cyclic flow of salt water related to geothermal heating in the. Floridan aquifer: New York Academy of Sciences Transactions, Series II, v. 28 , no. 2 , p. $249-271$. 
Kohout, F.A., 1967, Ground-water flow and the geothermal regime of the Floridan Plateau: Gulf Coast Association of Geological Societies, Transactions, v. XVII, p. 339-354.

McKenzie, D.J., 1976, Injection of acidic industrial waste into the Floridan aquifer near Belle Glade, Florida: Upward migration and geochemical interaction, 1973-75: U.S. Geological Survey Open-File Report $76-626,54 \mathrm{p}$.

McKenzie, D.J., and Irwin, G.A., 1984, Quality of water recovered from a municipal effluent injection well in the Floridan aquifer system, Pompano Beach, Florida: U.S. Geological Survey Water-Resources Investigations Report 84-4100, 23 p.

Merritt, M.L., 1985, Subsurface storage of freshwater in south Florida: A digital model analysis of recoverability: U.S. Geological Survey Water-Supply Paper 2261, 44 p.

Merritt, M.L., Meyer, F.W., Sonntag, W.H., and Fitzpatrick, D.J., 1983, Subsurface storage of freshwater in south Florida: A prospectus: U.S. Geological Survey Water-Resources Investigations Report 83-4214.

Meyer, F.W., 1971, Preliminary evaluation of the hydrologic effects of implementing water and sewerage plans, Dade County, Florida: U.S. Geological Survey Open-File Report FL-71003, $110 \mathrm{p}$.

-.--- 1974, Evaluation of hydraulic characteristics of a deep artesian aquifer from natural waterlevel fluctuations, Miami, Florida: Florida Bureau of Geology Report of Investigations 75, $32 \mathrm{p}$.

-.-. 1984, Disposal of liquid wastes in cavernous dolostones beneath southeastern Florida, in A. Burger and L. Dubertret, eds., Hydrogeology of karstic terrains, case histories: International Association of Hydrogeologists, v. 1, p. $211-216$.

1987, Summary of well construction testing and preliminary findings from the Alligator Alley test well, Broward County, Florida: U.S. Geological Survey Open-File Report 87-551, 68 p.
Miller, J.A., 1979, Potential subsurface zones for liquid-waste storage in Florida: Florida Bureau of Geology Map Series 94, 1 sheet.

-.--1986, Hydrogeologic framework of the Floridan aquifer system in Florida and in parts of Georgia, Alabama, and South Carolina: U.S. Geological Survey Professional Paper 1403-B, $91 \mathrm{p}$.

Parker, G.G., Ferguson, G.E., Love, S.K, and others, 1955, Water resources of southeastern Florida, with special reference to the geology and ground water of the Miami area: U.S. Geological Survey Water-Supply Paper 1255, $965 \mathrm{p}$.

Singh, W.P., Eichler, G.E., Sproul, C.R., and Garcia-Bengochea, J.I., 1983, Pump testing Boulder Zone aquifer, south Florida: Journal of Hydraulic Engineering, v. 9, no. 8, p. 1152-1160.

Sproul, C.R., 1977, Spatial distribution of groundwater temperatures in south Florida, in Smith, D.L., and Griffin, G.M., eds., The geothermal nature of the Floridan Plateau: Florida Bureau of Geology Special Publication 21, p. 65-89.

Stringfield, V.T., 1936, Artesian water in the Florida Peninsula: U.S. Geological Survey Water-Supply Paper 773-C, p. 115-195.

-..--1953, Artesian water in southeastern states: Kentucky Geological Survey Special Publication no. 1, p. 24-39.

-.-- 1966, Artesian water in Tertiary limestone in the southeastern states: U.S. Geological Survey Professional Paper 517, 226 p.

Uchupi, Elazar, 1966, Map showing relation of land and submarine topography, De Soto Canyon to Grand Bahama Bank: U.S. Geological Survey Miscellaneous Investigations Series 1-475, scale 1:1,000,000 [1967].

U.S. Environmental Protection Agency, 1983, National revised primary drinking water regulations; advance notice of proposed rulemaking: Federal Register, v. 48, no. 194, part II, October 5, 1983, p. 45502-45521. 
Vecchioli, John, McKenzie, D.J., Pascale, C.A., and Wilson, W.E., 1979, Active waste-injection systems in Florida, 1976: U.S. Geological Survey Open-File Report 79-1296, 33 p.

Vernon, R.O., 1970, The beneficial uses of zones of high transmissivities in the Florida subsurface for water storage and waste disposal: Florida Bureau of Geology Information Circular 70, $39 \mathrm{p}$.
Wedderburn, L.A., and Knapp, M.S., 1983, Field investigation into the feasibility of storing freshwater in saline portions of the Floridan aquifer system, St. Lucie County, Florida: South Florida Water Management District Technical Publication 83-7,71 p. 